\title{
Recycling of Waste Expanded Polystyrene as an Effective Adsorbent of Naphthalene from Aqueous Solution
}

\author{
O. C. Taiwo, a,b T. J. Afolabi, ${ }^{a, b}$ F. N. Osuolale, ${ }^{a}$ A. O. Ajani, ${ }^{a}$ \\ O. A. Aworanti,a O. R. Ogunleye, a,b and A. O. Alade a,b,c* \\ a Department of Chemical Engineering, Ladoke Akintola University of Technology, \\ Ogbomoso, Nigeria

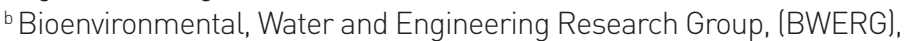 \\ Ladoke Akintola University of Technology, Ogbomoso, Nigeria \\ 'Science and Engineering Research Group, (SEARG), Ladoke Akintola University of Technology, \\ Ogbomoso, Nigeria
}

https://doi.org/10.15255/KUI.2020.084

KUI-37/2021

Original scientific paper

Received December 25, 2020

Accepted June 26, 2021

\begin{abstract}
Batch adsorption process factors [contact time (20-150 min), adsorbent dosage (0.5-1.5 g), adsorbate concentration (5-30 $\left.\mathrm{mg} \mathrm{l}^{-1}\right)$, and agitation rate (100-250 rpm)] were optimised based on D-optimal Design under the Response Surface Methodology (RSM) of the Design-Expert Software (7.6.8) for the removal of naphthalene from aqueous solution using adsorbent developed from Acetylated Waste Expanded Polystyrene (AWEPs). The maximum adsorption capacity $\left(5.6608 \mathrm{mg} \mathrm{g}^{-1}\right.$ ) achieved was well fitted to Dubinin-Radushkevich Isotherm $\left(R^{2}=0.9949\right)$. The SSE $(<0.05)$ and ARE $(<4.0 \%)$ indicated pseudo-second-order as the most suitable model. This research has demonstrated the effectiveness of the WEPs for the removal of naphthalene from the aqueous solution.
\end{abstract}

\section{Keywords}

Adsorption, D-optimal, naphthalene, waste expanded polystyrene

\section{Introduction}

Polycyclic aromatic hydrocarbons (PAHs) are a class of organic compounds characterised by two or more fused benzene rings. They are carcinogenic, mutagenic, and toxic. ${ }^{1}$ There are sixteen listed PAHs as priority pollutants that have been linked to various health challenges in humans. ${ }^{2,3}$ PAHs are by-products of various anthropogenic and industrial activities, such as incomplete combustion of coal, fuel, garbage, oil, oil spillage, organic substances, polymers, refuse, tobacco smoke, and wood, among others. $4,5,6,7$ The negative effect of PAHs in the environment has been a great concern to researchers ${ }^{8}$ to mitigate their serious effects on the human body. ${ }^{5,8,9}$

PAHs have a strong resistance to biological degradation, and some conventional physicochemical processes have not demonstrated the desired potency for their removal. ${ }^{5}$ However, adsorption processes, involving the use of activated carbon derived from synthetic, natural, and renewable sources have been deployed for the successful removal of PAHs. ${ }^{5,8,10}$ This may not be unconnected to the advantages of the ease in operation, cost-effectiveness, and insensitivity to toxic substances compared to other separation techniques. ${ }^{9}$ Activated carbon, commonly used in the adsorption process, has high adsorption capacities for a wide range of pollutants because of its porous microstructures and large surface areas. ${ }^{11}$ However, the purchase cost and the cost of regeneration of $\mathrm{AC}$ are expensive, ${ }^{12}$ besides there is $10-15 \%$ loss during regeneration. ${ }^{13} \mathrm{Ad}-$

*Corresponding author: Abass Olanrewaju Alade, PhD

Email: aoalade@lautech.edu.ng sorbents such as carbon nanotube, zeolite, diatomite, and organoclay have been used for the adsorption of PAHs from aqueous solutions. ${ }^{14,15,16}$ Naphthalene is an important $\mathrm{PAH}$ that has a molecule containing two benzene rings ${ }^{17}$ with molecular formula $\mathrm{C}_{10} \mathrm{H}_{8}$, obtainable from petroleum refining and coal tar distillation. ${ }^{18}$ Its presence in the environment is more pronounced, relative to the other types of PAHs. ${ }^{13}$ Some authors have used various types of adsorbent originated from clay, coal, and agricultural biomass for the removal of naphthalene from wastewater. ${ }^{19,20,21,22}$

Expanded polystyrene (EPS) are agglomerated small and expandable plastic "beads" used to produce food packages, ${ }^{23}$ because of their calendaring surface, which prevents absorption of water, oil, beverages, and other processed food products. Used EPS has relatively low scrap value and is discarded after use. ${ }^{24,25}$ Its non-biodegradable nature makes it persist in the environment and its build-up reduces the holding capacity of landfills or dumpsites. ${ }^{26,27}$ Reuse of EPS for environmental remediation is reported in the works of Gwenzi et al., Siyal et al., Alsewailem and Aljlil, and Ruziwa et al. ${ }^{26,27,28,29,30}$ This study aimed at recycling EPS waste into an effective adsorbent for the removal of naphthalene from the aqueous solution.

\section{Experimental}

\subsection{Materials and sample preparation}

WEPs, sourced from dumpsites were washed to remove oil and dirt from their surfaces. The collected WEPs were soaked in detergent solution and stirred until the strength 
of the detergent became weak. They were then rinsed thoroughly with a copious amount of distilled water before being sun-dried and oven-dried at $105^{\circ} \mathrm{C}$ to constant weight. They were reduced to relatively uniform sizes to reduce the impact of calendaring and expose the pores. ${ }^{30}$ All the reagents used in this research were of analytical grade and used without further purification. ${ }^{31}$

[Acetic acid $\left(\gamma: 60.052 \mathrm{~g} \mathrm{~mol}^{-1}, T_{\mathrm{b}}: 118{ }^{\circ} \mathrm{C}, \rho: 1.05 \mathrm{gcm}^{-3}\right.$, $T_{\mathrm{m}}: 16.6{ }^{\circ} \mathrm{C}$, CAS 64-19-7), $\mathrm{NaOH}\left(\gamma: 39.997 \mathrm{~g} \mathrm{~mol}^{-1}\right.$, $\rho: 2.13 \mathrm{~g} \mathrm{~cm}^{-3}, T_{\mathrm{b}}: 1,388{ }^{\circ} \mathrm{C}$, CAS 1310-73-2), Naphthalene $\left(T_{\mathrm{m}}: 80.26{ }^{\circ} \mathrm{C}, \gamma: 128.1705 \mathrm{~g} \mathrm{~mol}^{-1}, T_{\mathrm{b}}: 218{ }^{\circ} \mathrm{C}\right.$, $\rho: 1.14 \mathrm{~g} \mathrm{~cm}^{-3}$, CAS 91-20-3), Ethanol $\left(T_{\mathrm{b}}: 78.37{ }^{\circ} \mathrm{C}\right.$, $\gamma: 46.07 \mathrm{~g} \mathrm{~mol}^{-1}, T_{\mathrm{m}}:-114.1^{\circ} \mathrm{C}$, Density: $789 \mathrm{~kg} \mathrm{~m}^{-3}, \mathrm{CAS}$ 64-17-5)].

\subsection{Activation of WEPS}

The WEPs were mixed in $100 \mathrm{ml}$ of acetic acid ( $c=4.15 \mathrm{~mol} \mathrm{dm}^{-3}$ ) at a ratio of $1.5: 1$ (mass of activant/ mass of precursor) and microwaved in the oven at $600 \mathrm{~Hz}$ for $90 \mathrm{~min}$, the excess acid was boiled off. The $\mathrm{pH}$ of the acetylated WEPs (AWEPs) developed was neutralized with $\mathrm{NaOH}$ and oven-dried to constant weight. ${ }^{28,30}$

\subsection{Characterisation of AWEPS}

The ash and moisture contents were determined by the ASTM analytical method ${ }^{32}$ and the method adopted by Ekpete and Horsfall. ${ }^{33}$ The ash and moisture contents were calculated according to Eqs. (1) and (2). ${ }^{31}$ Fourier Transform Infrared Spectroscopy (FTIR) was used to determine the functional group on the surface of AWEPs before and after adsorption. The samples were prepared with potassium bromide at a $1: 10$ ratio and pressed into the pelletized disc. ${ }^{34}$ The FTIR spectrum of WEPs, AWEPs, and spent WEPs (SWEPs) adsorbents were recorded within the range of $400-4000 \mathrm{~cm}^{-1}$.

$$
\begin{aligned}
\text { ash content }(\%) & =\frac{m_{1}}{m_{2}} \cdot 100 \\
\% \text { moisture content } & =\frac{m_{4}-m_{3}}{m_{5}-m_{3}} \cdot 100
\end{aligned}
$$

where $m_{1}$ is the mass of ash, $m_{2}$ is the mass of the dried sample, $m_{3}$ is the mass of crucible, $m_{4}$ is the mass of crucible with the wet sample, and $m_{5}$ is the mass of the crucible with the dry sample.

\subsection{Batch adsorption}

\subsubsection{Adsorption studies}

A stock solution of naphthalene of $200 \mathrm{mg} \mathrm{l}^{-1}$ was prepared by dissolving $200 \mathrm{mg}$ of naphthalene in $100 \mathrm{ml}$ of ethanol. Distilled water was added to make $1 \mathrm{I}$. The stock solution was further diluted with distilled water accordingly to produce the desired concentration. ${ }^{35}$
The study type used for this experimental design for the adsorption study was the Response Surface Methodology (RSM). ${ }^{36}$ The initial design suggested by the Design-Expert software (7.6.8) was D-optimal. Zero (0) centre point was chosen for the design with no blocks selected, and a build time of $875 \mathrm{~min}$ was used for the design model. The factors are activant concentration (A), impregnation ratio (B), microwave time $(C)$, and microwave frequency $(D)$ while the response is adsorption capacity. ${ }^{26,28}$ Determined amount (0.5-1.5 g) of AWEPs was mixed with $100 \mathrm{ml}$ naphthalene solution of specific concentration (5-30 $\left.\mathrm{mgl}^{-1}\right)$ and shaken on a rotary shaker at a specific agitation rate (100-250 rpm), and at room temperature $\left(28 \pm 2{ }^{\circ} \mathrm{C}\right),{ }^{26,28}$ according to the D-optimal Design (Table 1). The mixture was centrifuged and the supernatant was analysed using UV-Spectrometer (UV-6100A, manufacturer: METASH A-MATRIX) at a wavelength of $275 \mathrm{~nm} \cdot{ }^{37}$ Different concentrations (5-50 mg |-1) of naphthalene were prepared earlier, and UV-Spectrometer (UV-6100A) at a wavelength of $275 \mathrm{~nm}$ was used to their corresponding absorbances, which were used to develop the calibration curve from which the equation for evaluating the naphthalene concentration from absorbance was determined. The adsorption capacity and removal efficiency were evaluated by Eqs. (3) and (4).

$$
\begin{gathered}
\text { adsorption capacity }\left(\frac{\mathrm{mg}}{\mathrm{g}}\right)=\frac{\left(\gamma_{\mathrm{o}}-\gamma_{t}\right) V}{m} \\
\operatorname{removal}(\%)=\frac{\gamma_{\mathrm{o}}-\gamma_{\mathrm{f}}}{C_{\mathrm{o}}}
\end{gathered}
$$

where $\gamma_{0}\left(\mathrm{mgl}^{-1}\right)$ is the initial concentration of naphthalene solution in contact with adsorbent, $\gamma_{\mathrm{t}}\left(\mathrm{mg} \mathrm{l}^{-1}\right)$ is the final concentration of naphthalene solution after the batch adsorption procedure at any time $t, m(\mathrm{~g})$ is the mass of adsorbent, and $V(\mathrm{I})$ is the volume of the naphthalene in solution.

Table 1 - Range of selected factors for naphthalene adsorption

\begin{tabular}{l|c|lc}
\hline Activation factors & Unit & \multicolumn{2}{|c}{ Ranges } \\
\hline naphthalene concentration & $\mathrm{mgl}^{-1}$ & 5.0 & High \\
\hline dosage & $\mathrm{g}$ & 0.5 & 30.0 \\
\hline time & $\mathrm{min}$ & 30 & 1.5 \\
\hline agitation rate & $\mathrm{rpm}$ & 100 & 60 \\
\hline
\end{tabular}

\subsubsection{Effect of adsorption factors}

The optimum conditions for the adsorption of naphthalene using AWEPs was subjected to OFAT procedures during which the effects of contact time and concentration were investigated when one of the factors was varied at a time. $38,39,40$

\subsection{Investigation of suitable adsorption isotherms}

The adsorption data obtained were fitted to selected isotherm models. Their constants were evaluated, and the 
correlation coefficient $\left(R^{2}\right)$ was used to express the extent of correlation between the experimental data and the model predicted values. ${ }^{41}$

\subsubsection{Langmuir isotherm model}

The Langmuir isotherm model is expressed by Eq. (5) and the linear form Eq. (6) was used to generate the plot of $\frac{\gamma_{\mathrm{e}}}{q_{\mathrm{e}}}$ against $\gamma_{\mathrm{e}}$, which gave a straight-line graph with a slope $\frac{1}{q_{\mathrm{m}}}$ and intercept of $\frac{1}{q_{\mathrm{m}} K_{\mathrm{L}}}$.

$$
\begin{gathered}
q_{\mathrm{e}}=\frac{q_{\mathrm{m}} K_{\mathrm{L}} \gamma_{\mathrm{e}}}{1+K_{\mathrm{L}} \gamma_{\mathrm{e}}} \\
\frac{\gamma_{\mathrm{e}}}{q_{\mathrm{e}}}=\frac{1}{q_{\mathrm{m}} K_{\mathrm{L}}}+\frac{\gamma_{\mathrm{e}}}{q_{\mathrm{m}}}
\end{gathered}
$$

where $q_{\mathrm{e}}$ is the adsorption capacity at equilibrium $\left(\mathrm{mgg}^{-1}\right)$, $\gamma_{e}$ is the equilibrium concentration of the adsorbate solution $\left(\mathrm{mgl}^{-1}\right), K_{\mathrm{L}}$ is the constant related to the free energy of adsorption $\left(\mathrm{mg}^{-1}\right)$, and $q_{\mathrm{m}}$ is the maximum adsorption capacity at monolayer coverage $\left(\mathrm{mgg}^{-1}\right)$.

\subsubsection{Freundlich isotherm model}

The Freundlich isotherm model equation, Eq. (7), assumes a heterogeneous adsorbent surface with its adsorption sites at varying energy levels. Its linear form Eq. (8) was used to generate the plot of $\ln q_{\mathrm{e}}$ against $\ln \gamma_{\mathrm{e}}$ that is needed to determine the Freundlich constants $\left(k_{\mathrm{F}}\right.$ and $\left.1 / n\right) .{ }^{42}$

$$
\begin{gathered}
q_{\mathrm{e}}=k_{\mathrm{F}} \gamma_{\mathrm{e}}^{\frac{1}{n}} \\
q_{\mathrm{e}}=\frac{1}{n} \ln \gamma_{\mathrm{e}}+\ln k_{\mathrm{F}}
\end{gathered}
$$

where $k_{\mathrm{F}}$ is the Freundlich constant, and $q_{\mathrm{e}}$ is the adsorption capacity at equilibrium $\left(\mathrm{mgg}^{-1}\right)$

\subsubsection{Temkin isotherm model}

Temkin isotherm model explicates that the adsorbate-adsorbent interactions and the related change in heat and/or energy of adsorption are assumed to be linear ---+-characterised by a uniform distribution of binding energy and up to some maximum binding energy. ${ }^{42}$ Such an assumption cannot hold for a logarithmic relationship. The Temkin isotherm model is expressed by Eq. (9), while its linear form is expressed by Eq. (10), and was further simplified to Eq. (11).

$$
\begin{gathered}
q_{\mathrm{e}}=\frac{R T}{b} \ln \left(A \gamma_{\mathrm{e}}\right) \\
q_{\mathrm{e}}=\frac{R T}{b} \ln A+\frac{R T}{b} \log \gamma_{\mathrm{e}}
\end{gathered}
$$

$$
q_{\mathrm{e}}=B \ln A+B \ln \gamma_{\mathrm{e}}
$$

where $B=R T / b, B$ is the molecular interaction parameter related to the heat of adsorption. $A$ and $B$ are the Temkin isotherm constants, $T(\mathrm{~K})$ is the absolute temperature, and $R$ is the ideal gas constant $\left(8314 \mathrm{~J} \mathrm{~mol}^{-1} \mathrm{~K}^{-1}\right)$.

\subsubsection{Dubinin-Radushkevich isotherm}

Dubinin-Radushkevich (D-R) isotherm Eq. (12) assumes that pore filling influenced the adsorption mechanism in micropores and not a layer-by-layer formation of a film in the walls of the adsorbent pores. ${ }^{43}$ The linear form of the $\mathrm{D}-\mathrm{R}$ isotherm equation is expressed in Eq. (13) and was used to plot $\ln q_{\mathrm{e}}$ against $\varepsilon^{2}$ needed to determine the $q_{\mathrm{m}}$ and $\beta$ from the intercept and slope.

$$
\begin{gathered}
q_{\mathrm{e}}=q_{\mathrm{m}} \mathrm{e}^{-\beta \varepsilon^{2}} \\
\ln q_{\mathrm{e}}=\ln q_{\mathrm{m}}-\beta \varepsilon^{2}
\end{gathered}
$$

where $\beta\left(\mathrm{KJ}^{2} \mathrm{~mol}^{2}\right)$ is the free energy of sorption per mole of the naphthalene as it migrates to the surface of WEPs from an infinite distance in the solution, $q_{\mathrm{m}}$ is the maximum adsorption capacity, and $\varepsilon$ is the Polanyi potential $\left(\mathrm{mol}^{-1}\right)$, which is expressed by Eq. (14):

$$
\varepsilon=R T \ln \left(1+\frac{1}{\gamma_{\mathrm{e}}}\right)
$$

where $R$ is the universal gas constant $\left(8.314 \mathrm{~J} \mathrm{~mol}^{-1} \mathrm{~K}^{-1}\right), T$ is the absolute temperature $(\mathrm{K})$, and $\gamma_{\mathrm{e}}$ is the equilibrium concentration of naphthalene.

\subsection{Adsorption kinetics studies}

The pseudo-first-order model, pseudo-second-order mod$\mathrm{el}$, and intraparticle diffusion model were employed to evaluate the experimental data generated in this study.

\subsubsection{Pseudo-first-order model}

This model (Eq. (15)) is based on a solid capacity and its plot of $\ln \left(q_{\mathrm{e}}-q_{\mathrm{t}}\right)$ vs $t$ that gives a straight line from which $K_{1}$ and $q_{\mathrm{t}}$ were evaluated based on the slope and intercept.

$$
\ln \left(q_{\mathrm{e}}-q_{\mathrm{t}}\right)=\ln q_{\mathrm{t}}-K_{1} t
$$

where $q_{\mathrm{e}}$ is the equilibrium adsorption capacity $\left(\mathrm{mgg}^{-1}\right), q_{\mathrm{t}}$ is the adsorption capacity at time $\left(\mathrm{mg} \mathrm{g}^{-1}\right), K_{1}$ is the pseudo-first-order rate constant $\left(\mathrm{min}^{-1}\right)$, and $t$ is the time taken.

\subsubsection{Pseudo-second-order model}

This model (Eq. (16)) was used to plot $t / q_{\mathrm{e}} v s t$, which gave a straight line from which $q_{\mathrm{e}}$ and $K_{2}$ were evaluated. 


$$
\frac{t}{q_{t}}=\frac{1}{q_{\mathrm{e}} K_{2}}+\frac{t}{q_{\mathrm{e}}}
$$

where $K_{2}$ is the rate constant of pseudo-second-order adsorption $\left(\mathrm{g} \mathrm{mg}^{-1} \mathrm{~min}^{-1}\right) .^{43}$

\subsection{Intraparticle diffusion model}

This model indicates that the rate-limiting step is the transport of the solute from the bulk of the solution to the adsorbent pores through the intraparticle process. It was expressed according to Eq. (17): ${ }^{44}$

$$
q_{t}=k_{\text {diff }} t^{\frac{1}{2}}+C
$$

where $k_{\text {diff }}$ is the intraparticle diffusion rate constant $\left(\mathrm{mg} \mathrm{g}^{-1} \mathrm{~min}^{-0.5}\right), t$ is time, and $\mathrm{C}$ is constant.

\subsection{Test of the kinetics model}

The impact of various error functions on the predicted isotherm parameters was analysed to determine the order of suitability of the selected isotherm models. Error functions such as Average Relative Error (ARE) and Sum of Error Square (SSE) were calculated according to the Eqs. (16) and (17). ${ }^{45,46}$

$$
\begin{gathered}
\operatorname{ARE}=\frac{100}{n} \sum_{i=1}^{n}\left|\frac{q_{e, \text { exp }}-q_{\mathrm{e}, \mathrm{cal}}}{q_{\mathrm{e}, \mathrm{exp}}}\right| \\
\mathrm{SSE}=\sum_{i=1}^{n} \frac{\left(q_{\mathrm{e}, \mathrm{cal}}-q_{\mathrm{e}, \mathrm{exp}}\right)^{2}}{n}
\end{gathered}
$$

where $q_{\mathrm{e}, \exp }$ is the adsorption capacity at equilibrium experimental $\left(\mathrm{mg} \mathrm{g}^{-1}\right), q_{\mathrm{e}, \text { cal }}$ is the adsorption capacity at equilibrium calculated $\left(\mathrm{mg} \mathrm{g}^{-1}\right)$, and $n$ is the number of data points.

\section{Results and discussion}

\subsection{Physicochemical analysis of the adsorbent}

There was a significant difference in the ash content between the WEPs $(0.10 \%)$ and AWEPs $(0.39 \%)$ (Table 2$)$. This may be due to the impact of the activant on the composition of the untreated WEPs, and this further suggested that the activation process was evident. ${ }^{47,48}$ The moisture content of AWEPs (14.82 \%) was higher than that of WEPs $(0.90 \%)$, and this may be due to the soaking step during the activation process.

\subsection{FTIR characterisation of WEPs and AWEPs}

The IR peaks observed in the WEPs ranged from $623.1 \mathrm{~cm}^{-1}$ to $3933.4 \mathrm{~cm}^{-1}$ and the peak height ranged from $21.8 \mathrm{~cm}^{-1}$ to $36.9 \mathrm{~cm}^{-1}$ (Fig. 1a). AWEPs had IR peaks
Table 2 - Proximate analysis of WEPS and AWEPS

\begin{tabular}{c|c|c}
\hline Sample & Ash content $/ \%$ & Moisture content $/ \%$ \\
\hline WEPs & 0.10 & 0.90 \\
\hline AWEPs & 0.39 & 14.82 \\
\hline
\end{tabular}

WEPs - Waste Expanded Polystyrene, AWEPs -

Acetylated Waste Expanded Polystyrene

that ranged from $613.7 \mathrm{~cm}^{-1}$ to $3892.3 \mathrm{~cm}^{-1}$ and peak height ranged from $3.5 \mathrm{~cm}^{-1}$ to $21.8 \mathrm{~cm}^{-1}$. The IR peak for the spent SAWEPs ranged from $618.5 \mathrm{~cm}^{-1}$ to 3930.4 , while the peak height ranged from $10 \mathrm{~cm}^{-1}$ to $27.4 \mathrm{~cm}^{-1}$. The IR peaks observed in the WEPs shifted from (623.1$\left.3933.4 \mathrm{~cm}^{-1}\right)$ to $\left(613.7-3892.3 \mathrm{~cm}^{-1}\right)$ on AWEPs. All these changes suggested the impact of acetic acid activation on the surface improvement of the WEPs. The aromatic $\mathrm{C}-\mathrm{H}$ band present in both WEPs and AWEPs is attributed to the presence of an aromatic benzene ring that is not split by the acidic modification on the WEPs. $\mathrm{C}-\mathrm{C}-\mathrm{O}$ at $1332 \mathrm{~cm}^{-1}$ was found in WEPs but disappeared in AWEPs due to the modification by acetic acid. These bands indicate the possible involvement of these functional groups on the surface of AWEPs in the naphthalene adsorption process. ${ }^{47}$ WEPS and AWEPs surface chemistry were found to be different as some of the functional groups such as $\mathrm{O}-\mathrm{H}$ and $\mathrm{C}-\mathrm{C}-\mathrm{O}$ disappeared due to the activation process. ${ }^{48}$

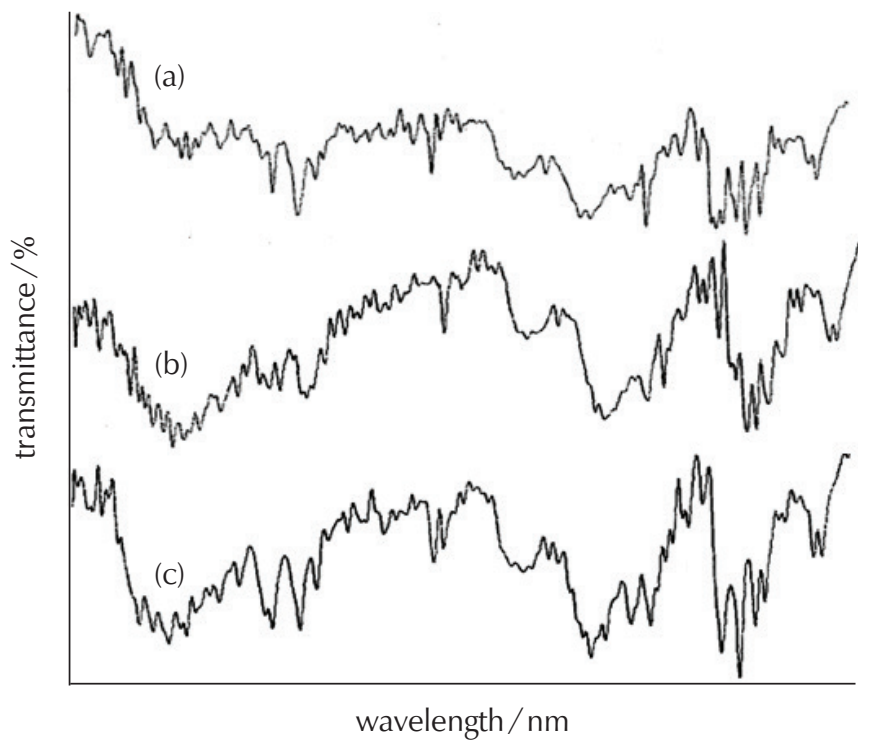

Fig. 1 - FTIR spectra for (a) Waste Expanded Polystyrene, (b) Acetylated Waste Expanded Polystyrene, and (c) Spent Acetylated Waste Expanded Polystyrene

\subsection{Design summary for the adsorption capacity of AWEPs for naphthalene}

Run 4 (60 min, $100 \mathrm{rpm}, 5 \mathrm{mg} \mathrm{l}^{-1}$, and $1.5 \mathrm{~g}$ ) gave the lowest adsorption capacity $\left(0.1623 \mathrm{mg} \mathrm{g}^{-1}\right)$, while Run 3 (30 min, $100 \mathrm{rpm}, 30 \mathrm{mgl}^{-1}$, and $0.5 \mathrm{~g}$ ) gave the highest adsorption capacity (5.6608 $\mathrm{mg} \mathrm{g}^{-1}$ ) (Table 3), which 
Table 3 - Results of responses from adsorption experimental data

\begin{tabular}{|c|c|c|c|c|c|}
\hline \multirow{2}{*}{ Run } & \multicolumn{4}{|c|}{ Factors } & \multirow{2}{*}{$\begin{array}{c}\text { Response } \\
\text { adsorption capacity } / \mathrm{mgg}^{-1}\end{array}$} \\
\hline & A: time $/ \min$ & B: agitation rate/rpm & $\mathrm{C}$ : concentration $/ \mathrm{mg} \mathrm{I}^{-1}$ & D: dosage/g & \\
\hline 1 & 30.00 & 100.00 & 17.50 & 1.50 & 0.6188 \\
\hline 2 & 45.00 & 250.00 & 30.00 & 1.50 & 0.7565 \\
\hline 3 & 30.00 & 100.00 & 30.00 & 0.50 & 5.6608 \\
\hline 4 & 60.00 & 100.00 & 5.00 & 1.50 & 0.1623 \\
\hline 5 & 30.00 & 100.00 & 5.00 & 0.50 & 0.4869 \\
\hline 6 & 60.00 & 100.00 & 30.00 & 1.50 & 1.4231 \\
\hline 7 & 30.00 & 250.00 & 5.00 & 1.50 & 0.3072 \\
\hline 8 & 30.00 & 250.00 & 17.50 & 0.50 & 2.8130 \\
\hline 9 & 60.00 & 100.00 & 17.50 & 0.50 & 2.9000 \\
\hline 10 & 30.00 & 175.00 & 30.00 & 1.50 & 1.3072 \\
\hline 11 & 60.00 & 250.00 & 5.00 & 0.50 & 0.9217 \\
\hline 12 & 60.00 & 100.00 & 30.00 & 1.50 & 1.3072 \\
\hline 13 & 30.00 & 100.00 & 30.00 & 0.50 & 3.0521 \\
\hline 14 & 60.00 & 250.00 & 17.50 & 1.50 & 0.5898 \\
\hline 15 & 60.00 & 250.00 & 30.00 & 0.50 & 4.4434 \\
\hline 16 & 60.00 & 175.00 & 17.50 & 1.00 & 0.4065 \\
\hline 17 & 30.00 & 250.00 & 5.00 & 1.50 & 1.9608 \\
\hline 18 & 45.00 & 250.00 & 17.50 & 1.00 & 0.9717 \\
\hline 19 & 60.00 & 250.00 & 30.00 & 0.50 & 4.7043 \\
\hline 20 & 30.00 & 100.00 & 5.00 & 0.50 & 0.9838 \\
\hline 21 & 30.00 & 175.00 & 17.50 & 1.00 & 0.4500 \\
\hline 22 & 45.00 & 100.00 & 17.50 & 1.00 & 1.3630 \\
\hline 23 & 45.00 & 175.00 & 23.75 & 1.00 & 2.2489 \\
\hline 24 & 45.00 & 175.00 & 5.00 & 1.00 & 0.3304 \\
\hline 25 & 30.00 & 250.00 & 30.00 & 1.00 & 2.2217 \\
\hline
\end{tabular}

is higher than adsorption capacity of $1.44,1.595,1.527$, and $4.39 \mathrm{mg} \mathrm{g}^{-1}$, reported by Ania et al., ${ }^{49}$ Murilo et al., ${ }^{10}$ and Alade et al., ${ }^{8}$ for activated carbons, activated clay, and flamboyant pod activated carbon studied for the removal of naphthalene. A quadratic model was selected for this study because of its least standard deviation (10.33) and high $R^{2}(0.9835)$. The $R^{2}(0.9548)$ was very close to the adjusted $R^{2}$ of 0.9548 , with less than 0.2 differences, as normally expected. ${ }^{44}$ This indicated no large block effect nor any possible problem with the model and data obtained. ${ }^{50}$ Adequate Precision, which measures the signal-to-noise ratio of the data, was 28.793, which was greater than the desired value (4.0), thus making the developed model very suitable to navigate the design space. ${ }^{51}$

\subsection{Analysis of variance (ANOVA) for adsorption capacity of AWEPs}

Prob $>\mathrm{F}$ of any term or model, less than 0.05, at a $95 \%$ confidence interval is taken as significant. ${ }^{31}$ The model F-value of 34.16 implies the model is significant and it has about $0.01 \%$ chance of occurrence due to noise. Thus, C, $\mathrm{AB}, \mathrm{AC}, \mathrm{AD}, \mathrm{BC}, \mathrm{BD}$, and $\mathrm{CD}$ are significant model terms (Table 4). The "Lack of fit F-value" of 0.63 implies the Lack of fit is not significant relative to the pure error, which makes the model $\mathrm{fit}^{31}$ and there is a $62.61 \%$ chance that a "Lack of fit F-value" this large could occur due to noise. This is further illustrated by Fig. 2, showing the effects of the model terms concerning Normal \% probability. The points are distributed on the normal line starting from approximately 2 to $97 \%$ on normal percentage distribution, Y-axis, and -1.5 to 2.5 on internally studentized residuals, $\mathrm{X}$-axis though there is a stacking of the points. ${ }^{31}$ 
Table 4 - ANOVA for the Model and selected factors

\begin{tabular}{|c|c|c|c|c|c|}
\hline Source & Sum of squares & $D_{f}$ & Mean square & F value & P-value Prob $>F$ \\
\hline Model & 51038.03 & 14 & 3645.57 & 34.16 & $<0.0001^{*}$ \\
\hline A - time & 14.27 & 1 & 14.27 & 0.13 & 0.7240 \\
\hline $\mathrm{B}$ - agitation rate & 25.36 & 1 & 25.36 & 0.24 & 0.6390 \\
\hline C - concentration & 5903.74 & 1 & 5903.74 & 55.32 & $<0.0001^{*}$ \\
\hline D - dosage & 113.17 & 1 & 113.17 & 1.06 & 0.3332 \\
\hline $\mathrm{AB}$ & 2923.37 & 1 & 2923.37 & 27.39 & $0.0008^{*}$ \\
\hline$A C$ & 7680.27 & 1 & 7680.27 & 71.97 & $<0.0001^{*}$ \\
\hline$A D$ & 1786.01 & 1 & 1786.01 & 16.74 & $0.0035^{*}$ \\
\hline $\mathrm{BC}$ & 8533.81 & 1 & 8533.81 & 79.97 & $<0.0001^{*}$ \\
\hline $\mathrm{BD}$ & 1517.79 & 1 & 1517.79 & 14.22 & $0.0055^{*}$ \\
\hline $\mathrm{CD}$ & 5305.82 & 1 & 5305.82 & 49.72 & $0.0001^{*}$ \\
\hline $\mathrm{A}^{2}$ & 39.15 & 1 & 39.15 & 0.37 & 0.5615 \\
\hline $\mathrm{B}^{2}$ & 0.21 & 1 & 0.21 & $1.939 \cdot 10^{-3}$ & 0.9660 \\
\hline $\mathrm{C}^{2}$ & 37.79 & 1 & 37.79 & 0.35 & 0.5683 \\
\hline $\mathrm{D}^{2}$ & 69.13 & 1 & 69.13 & 0.65 & 0.4442 \\
\hline Residual & 853.71 & 8 & 106.71 & & \\
\hline Lack of fit & 234.40 & 3 & 78.13 & 0.63 & 0.6261 \\
\hline Pure error & 619.32 & 5 & 123.86 & & \\
\hline Cor total & 51891.75 & 22 & & & \\
\hline
\end{tabular}

${ }^{*}$ Significant at $p<0.05$

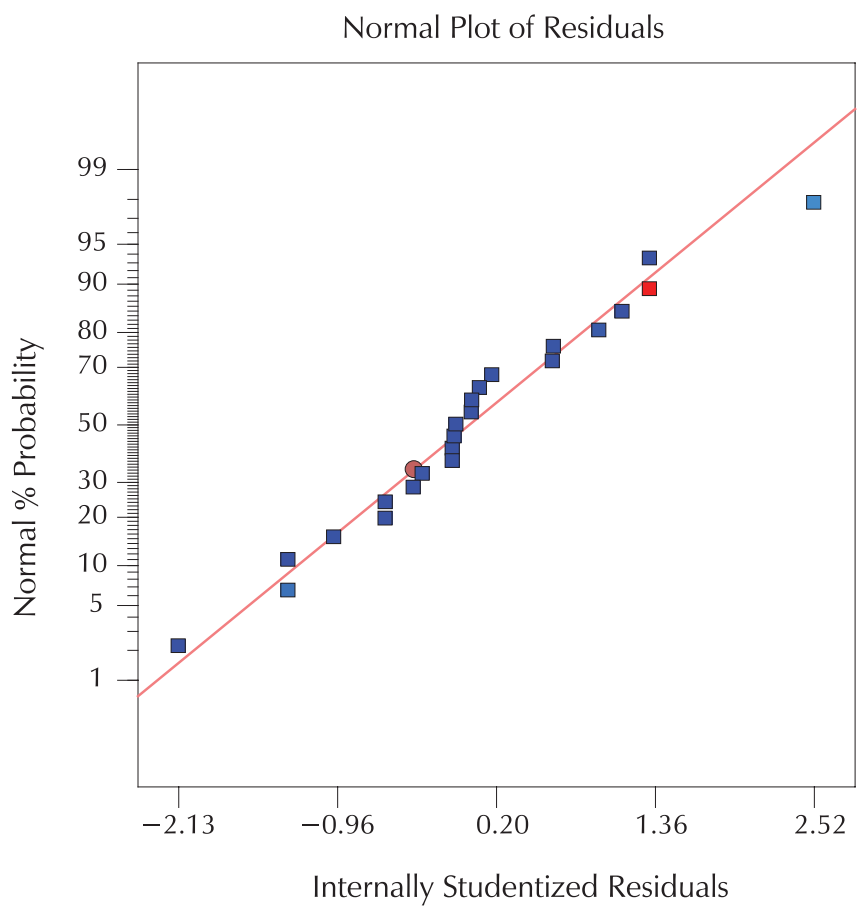

Fig. 2 - Effects of the model terms with respect to normal \% probability

\subsection{Model equation}

The model equations, (Eqs. (18) and (19)), show the relationship between the adsorption capacity and the selected factors that can be used to predict the naphthalene adsorption. Model terms $\mathrm{B}, \mathrm{D}, \mathrm{AD}, \mathrm{B}^{2}, \mathrm{~A}^{2}, \mathrm{C}^{2}$, and $\mathrm{D}^{2}$ have positive coefficients, which indicate an increase in the adsorption capacity of AWEPs in the factors. The negative coefficients as observed in $\mathrm{A}, \mathrm{C}, \mathrm{AB}, \mathrm{AC}, \mathrm{BD}, \mathrm{CD}$, and $\mathrm{B}^{2}$ indicate an antagonistic influence of these factors on the adsorption capacity of naphthalene. The empirical model equations in terms of coded factors are given in Eq. (18), for the significant and non-significant terms.

$$
\begin{gathered}
(\text { adsorption capacity })^{-3}=+3.01-1.83 \mathrm{~A}+ \\
+2.46 \mathrm{~B}-25.23 \mathrm{C}+6.27 \mathrm{D}-30.38 \mathrm{AB}- \\
-31.98 \mathrm{~A}+24.36 \mathrm{AD}+33.65 \mathrm{BC}-22.59 \mathrm{BD}- \\
-24.79 \mathrm{CD}+8.26 \mathrm{~A}^{2}-0.6 \mathrm{~B}^{2}+7.35 \mathrm{C}^{2}+19.45 \mathrm{D}^{2}
\end{gathered}
$$

$\mathrm{A} B, \mathrm{C}$, and $\mathrm{D}$ are the coded variables for activant concentration, IMR, microwave time, and frequency, respectively.

\subsection{Model graph for the selected factors on adsorption capacity for naphthalene}

The plot of agitation rate with time (Fig. 3) shows a gradual decrease in adsorption capacity before a steep slope moving upward, and this indicates that the two factors cause a decrease, and then finally increase the adsorption rate. There is a slight decrease in the slope of concentration against time before (Fig. 4) and thus, means that the 

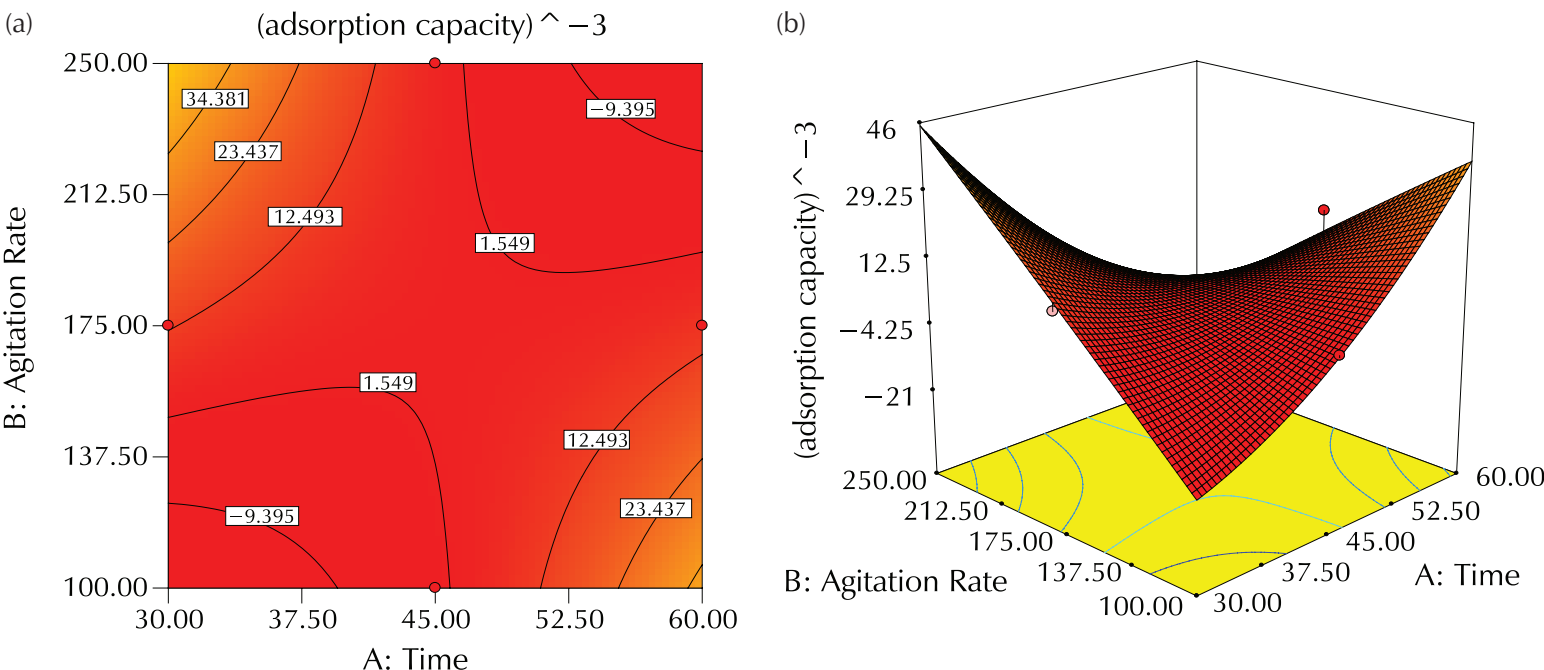

Fig. 3 - (a) Contour plot, and (b) 3D plot showing the relationship between time and agitation rate
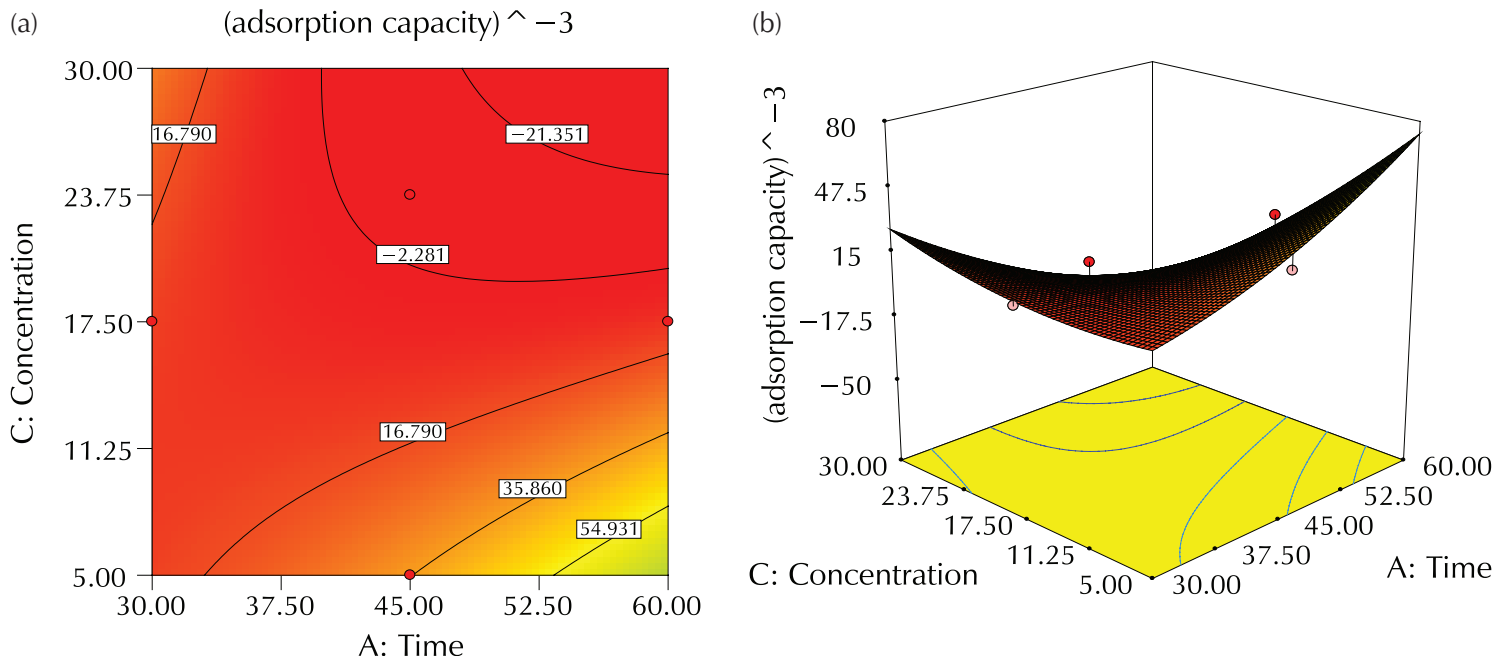

Fig. 4 - (a) Contour plot, and (b) 3D plot showing the relationship between time and concentration
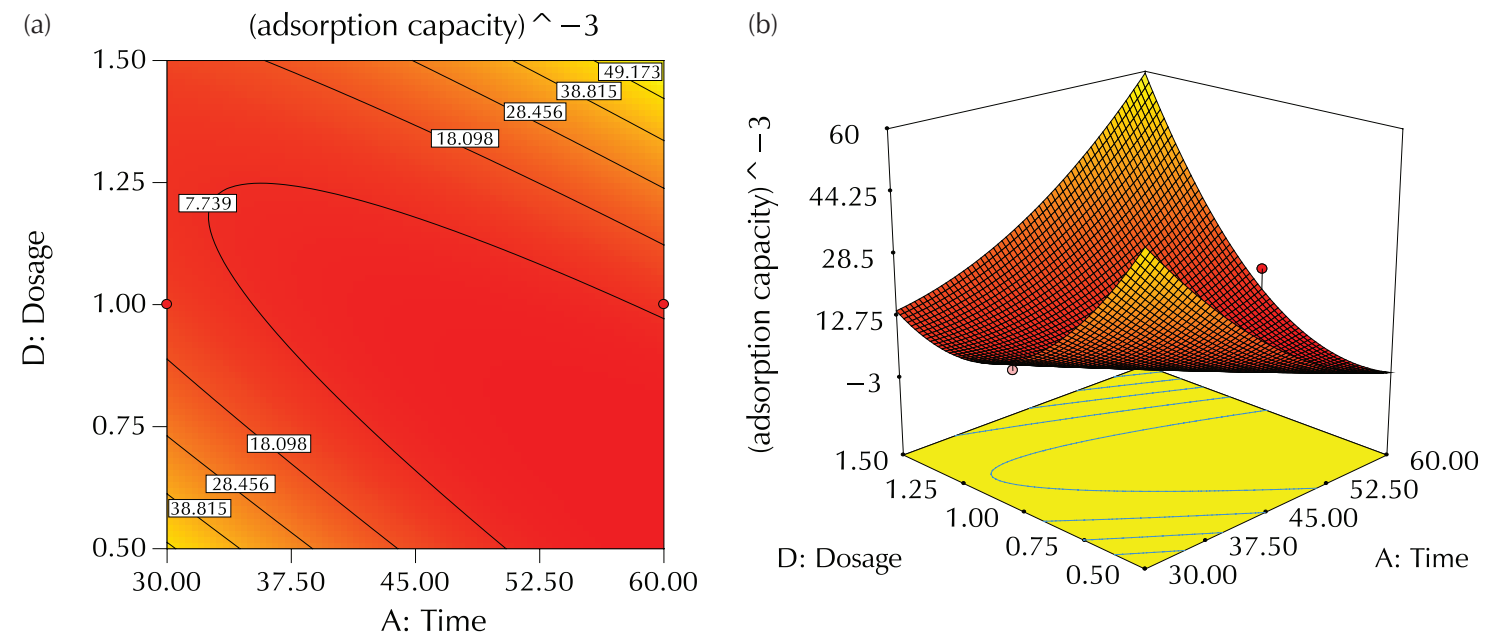

Fig. 5 - (a) Contour plot, and (b) 3D plot showing the relationship between dosage and time 


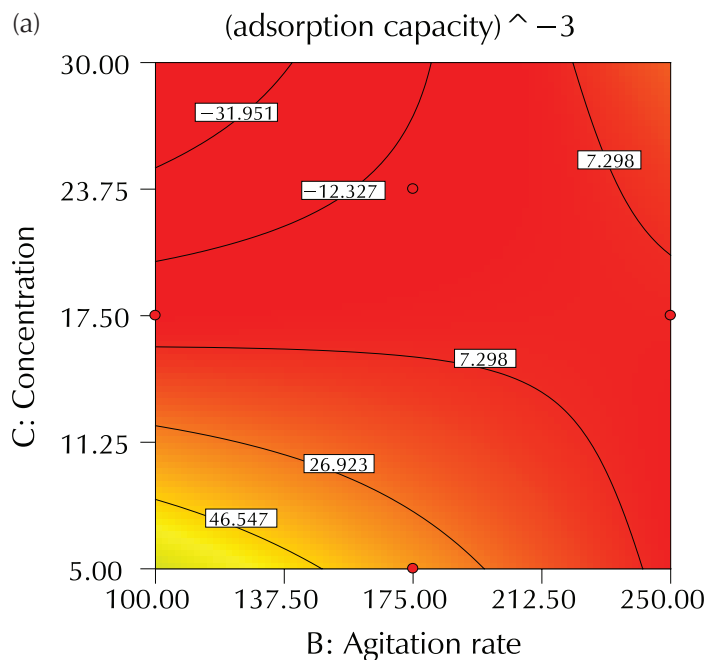

(b)

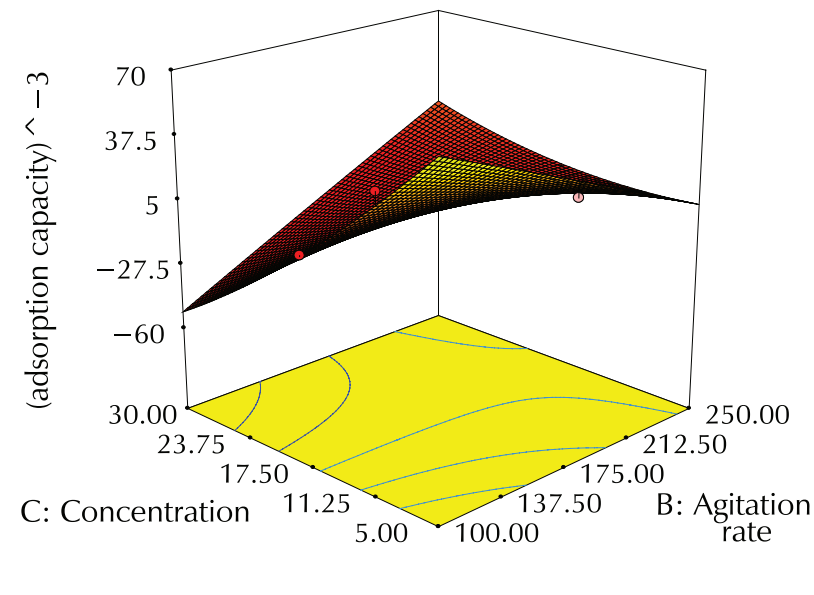

Fig. 6 - (a) Contour plot, and (b) 3D plot showing the relationship between concentration and agitation rate

(a)

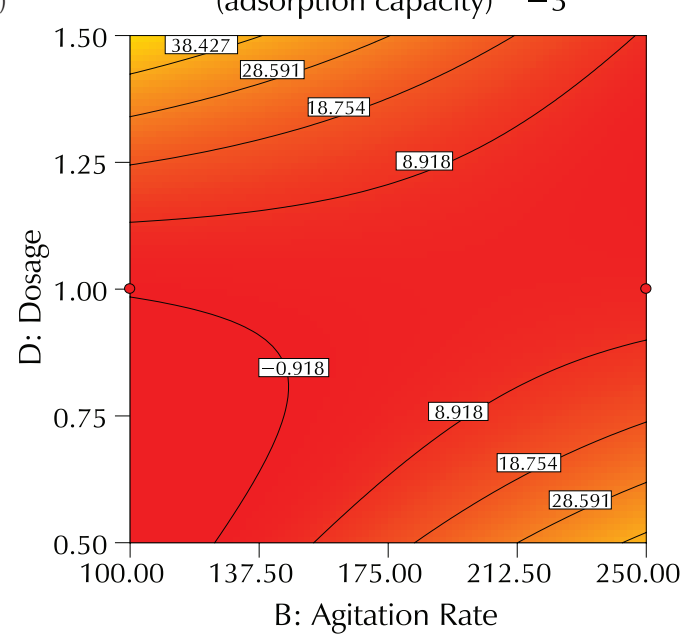

(b)

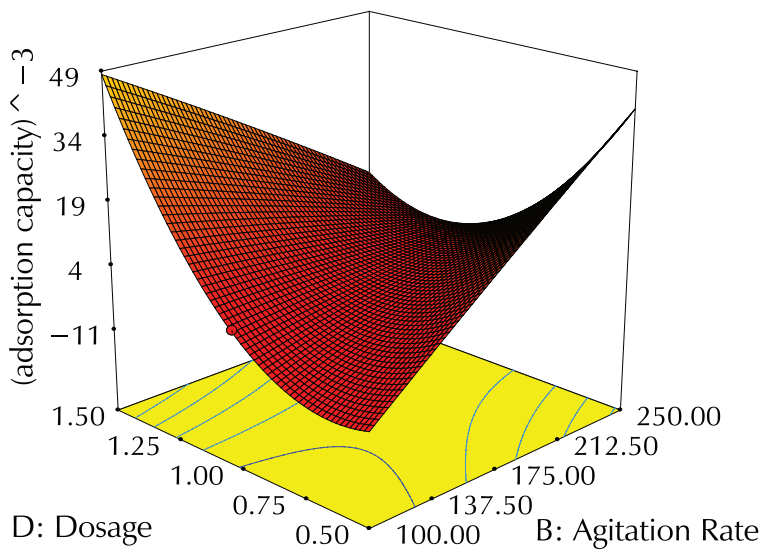

Fig. 7 - (a) Contour plot, and (b) 3D plot showing the relationship between dosage and agitation rate

(a)

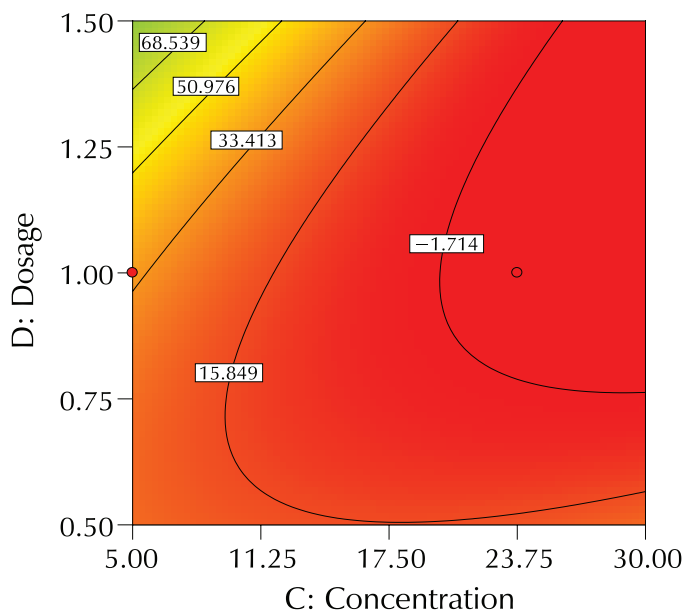

(b)

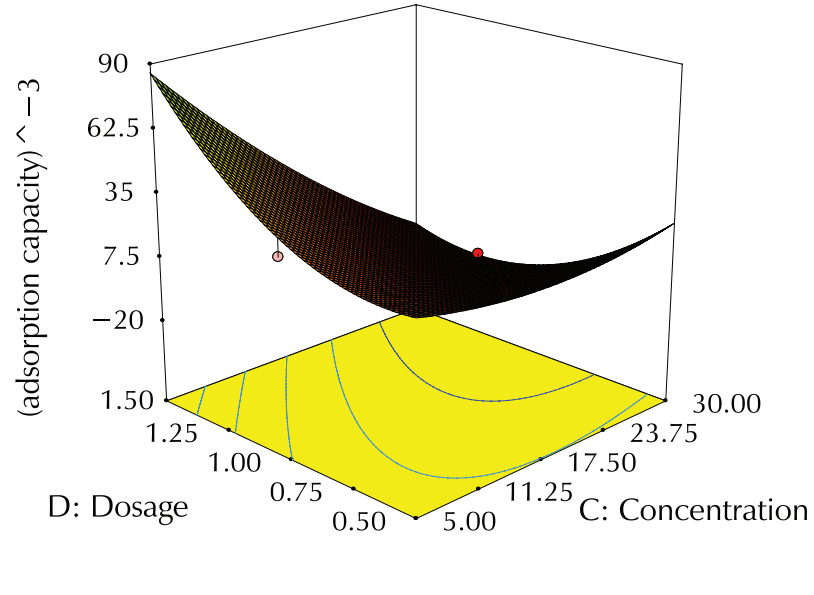

Fig. 8 - (a) Contour plot, and (b) 3D plot showing the relationship between dosage and concentration 
lower value of these factors decreases the adsorption rate. Contrary to Figs. 3 and 4, there is a parabolic curve, an increase in adsorption capacity in the plot of dosage and time (Fig. 5). Further increase in dosage value with time caused a decrease in adsorption capacity (Fig. 6). Concentration against the agitation rate plot shows an increase in adsorption capacity (Fig. 4). Other factors that increased the adsorption rate were the dosage value and agitation rate (Fig. 7 ), but the contrary result was experienced in Fig. 8, in which the dosage and concentration decreased with the adsorption rate.

\subsection{Numerical optimisation studies on adsorption capacity}

Numerical optimisation was obtained from the software. The four factors (time, agitation rate, concentration, and dosage) were all set to "is in range" (Table 4), while the adsorption capacity was set to "maximise" with its upper and lower limit, respectively. The desirability values were 0.994 , and the optimum values suggested by the software were $60 \mathrm{~min}, 100 \mathrm{rpm} 5 \mathrm{mgl}^{-1}$, and $1.5 \mathrm{~g}$ for time, agitation rate, concentration, and dosage, respectively (Fig. 9).

Table 5 - Selected factors used for optimisation showing their respective ranges

\begin{tabular}{c|c|c|c}
\hline Name & Goal & Lower Limit & $\begin{array}{c}\text { Upper } \\
\text { Limit }\end{array}$ \\
\hline time & is in range & 30 & 60 \\
\hline agitation rate & is in range & 100 & 250 \\
\hline concentration & is in range & 5 & 30 \\
\hline dosage & is in range & 0.5 & 1.5 \\
\hline (adsorption capacity) $^{\wedge}-3$ & maximise & 0.00551244 & 233.908 \\
\hline
\end{tabular}

\subsection{Effect of concentration on adsorption of naphthalene}

An increase in the adsorbate initial concentration (10-30 $\mathrm{mgl}^{-1}$ ) leads to an increase in the adsorption ca-
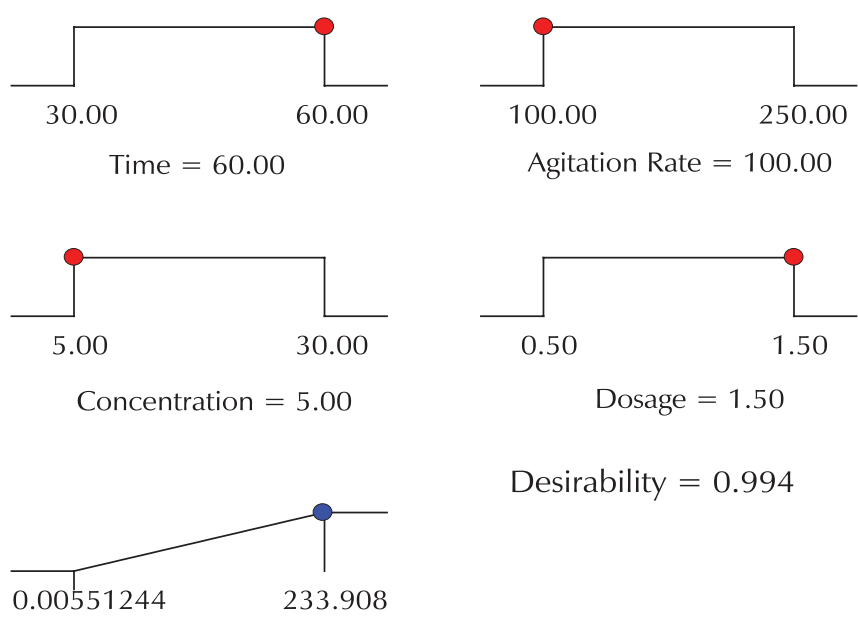

$(\text { adsorption capacity })^{\wedge}-3=232.434$

Fig. 9 - Graphical representation of the numerical optimisation

pacity (1.921-5.9217 $\mathrm{mg} \mathrm{g}^{-1}$ ) of the adsorbent due to the increase in the driving force of the concentration gradient (Fig. 10a). The adsorption of naphthalene was rapid at the initial stage of the contact time (30 min) for all the concentrations. This was because, in the beginning, all active sites on the adsorbent were vacant, hence, adsorption proceeded at a faster rate. After this, the rates of adsorption and desorption tended to be equal, and the extent of adsorption reduced and eventually became almost constant at equilibrium. ${ }^{51}$ The percentage of removal also increased with increasing time for all the concentrations (Fig. 10b).

\subsection{Effect of dosage on the adsorption of naphthalene}

An increase in adsorbent dosage (0.5-2.5 g) led to a reduction (5.5739-1.1930 $\mathrm{mg} \mathrm{g}^{-1}$ ) in adsorption capacity (Fig. 11a), because of the effect of partial aggregation of naphthalene on the adsorbent surface, resulting in a decrease in total surface area available for naphthalene molecules. An increase in the adsorbent dosage increased the removal efficiency of naphthalene from $92.9 \%$ to $99.4 \%$
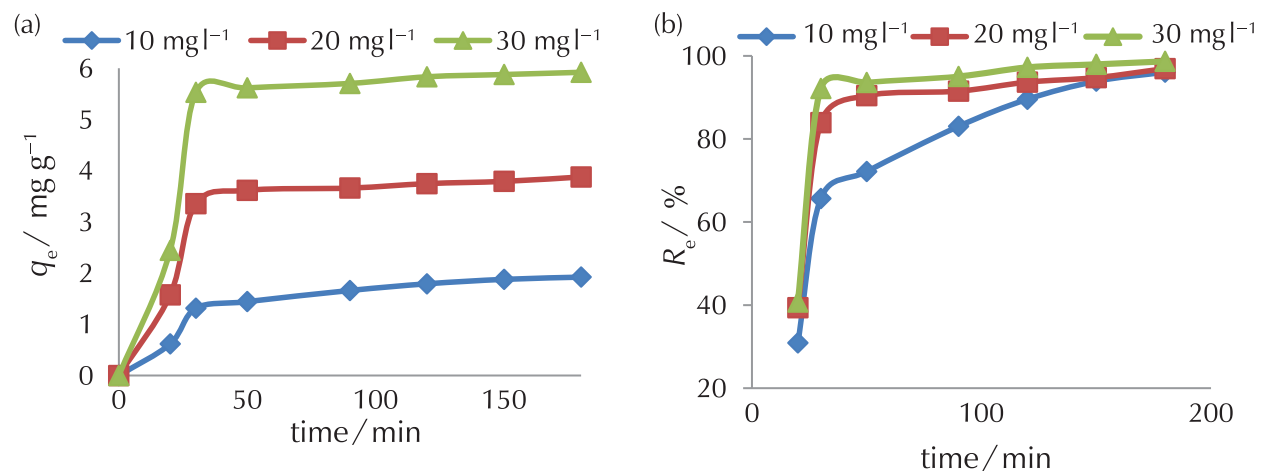

Fig. 10 - Effect of concentration on (a) adsorption capacity, and (b) removal efficiency 

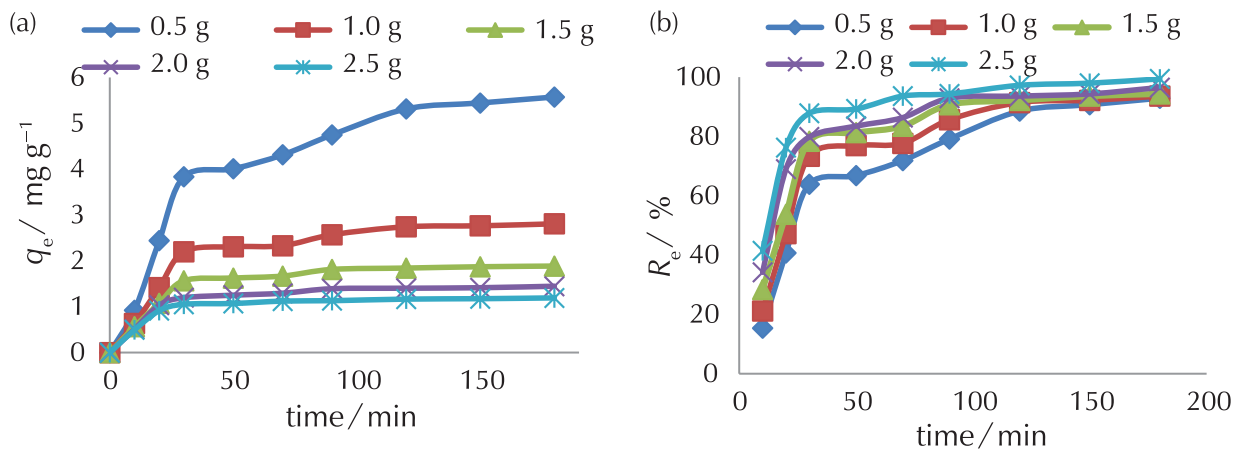

Fig. 11 - Effect of adsorbent dosage on (a) adsorption capacity, and (b) removal efficiency

at $180 \mathrm{~min}$, due to the availability of more adsorption sites on the adsorbent (Fig. 11b). ${ }^{52,53}$

\subsection{Adsorption isotherm study}

\subsubsection{Langmuir isotherm model}

The values of $q_{\mathrm{m}}$ and $K_{\mathrm{L}}$ for AWEPs (Fig. 12) were $-8.7108 \mathrm{mgg}^{-1}$ and -0.1106 , respectively. The low value of $R^{2}(0.4238)$ indicated that the experimental equilibrium data were not well described by the Langmuir model. The maximum adsorption capacity $\left(q_{\mathrm{m}}\right)$ obtained from this research $\left(-8.7108 \mathrm{mg} \mathrm{g}^{-1}\right.$ ) (Table 5), was lower for the

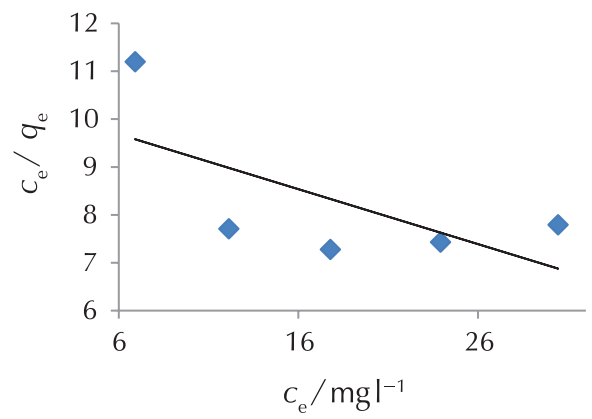

Fig. 12 - Plot of $c_{\mathrm{e}} / q_{\mathrm{e}}$ against $c_{\mathrm{e}}$ for the effect of concentration

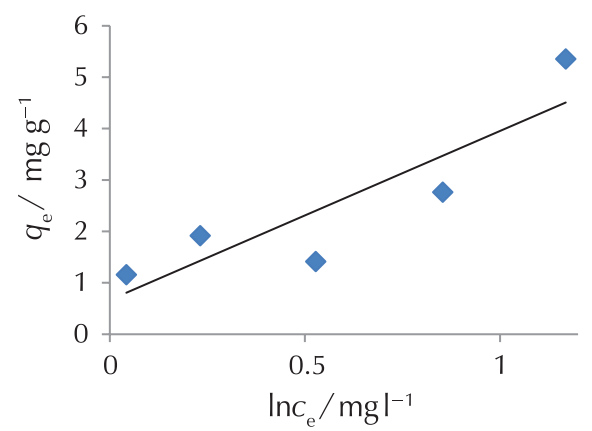

Fig. 14 - Plot of $q_{\mathrm{e}}$ against $\ln c_{\mathrm{e}}$ for the effect of concentration adsorption of naphthalene onto mesoporous molecular sieves, zeolite, Mesoporous organosilica, and banana peel activated carbon, respectively. ${ }^{10,54}$

\subsubsection{Freundlich isotherm model}

The Freundlich model to estimate $K_{\mathrm{f}}$ and $1 / n$ are $-0.0511 \mathrm{I} \mathrm{mg}^{-1}$ and 0.8059 from its intercepts and the slope, respectively (Fig. 13). The values of $1 / n$ ranging from 0 to 1 , indicates the model's favourability for the adsorption process, ${ }^{55}$ and this value is lower than the previous research, except 0.7986 derived by Gupta and Gupta. ${ }^{57}$ The negative $K_{\mathrm{f}}$ value obtained from this study was lower than

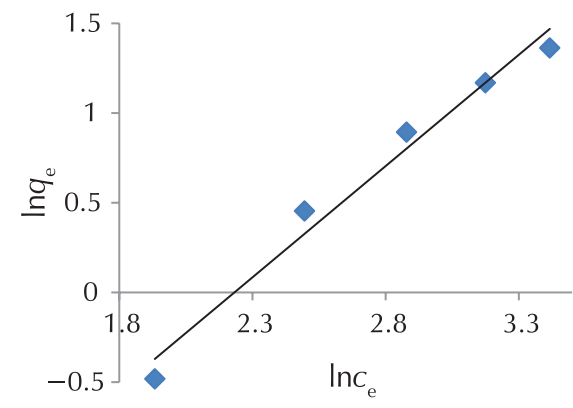

Fig. 13 - Plot of $\ln q_{\mathrm{e}}$ against $\ln c_{\mathrm{e}}$ for the effect of concentration

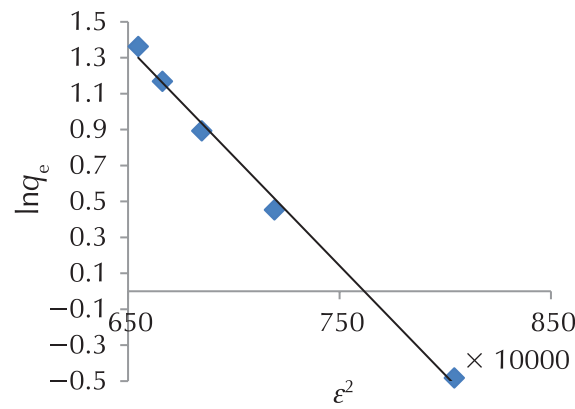

Fig. 15 - Plot of $\ln q_{\mathrm{e}}$ against $\varepsilon^{2}$ for the effect of concentration 
Table 6 - Comparison of Langmuir and Freundlich Isotherm Parameter to other studies

\begin{tabular}{|c|c|c|c|c|}
\hline \multirow{2}{*}{ Adsorbent } & \multirow{2}{*}{$\begin{array}{l}\text { Langmuir parameter } \\
\qquad q_{\mathrm{m}} / \mathrm{mgg}^{-1}\end{array}$} & \multicolumn{2}{|c|}{ Freundlich parameters } & \multirow{2}{*}{ Author } \\
\hline & & $K_{\mathrm{f}}$ & $1 / n$ & \\
\hline Mesoporous Molecular Sieves & 0.10624 & NR & NR & Murilo et al. $(2004)^{10}$ \\
\hline Zeolite & 0.769 & 4.215 & 1.074 & Chang et al. $(2004)^{56}$ \\
\hline Mesoporous Organosilica & 0.0466 & 0.227 & 0.97 & Carla et al. (2011) $)^{54}$ \\
\hline Banana Peel Activated Carbon & $\mathrm{NR}^{*}$ & 21.54 & 0.7986 & Gupta and Gupta (2015) ${ }^{5 t}$ \\
\hline AWEPS & -8.7108 & -0.0511 & 0.8059 & This study \\
\hline
\end{tabular}

${ }^{*} \mathrm{NR}$ - not reported

the $K_{\mathrm{f}}$ value derived by Carla et al., ${ }^{54}$ Chang et al., ${ }^{56}$ Gupta and Gupta, ${ }^{57}$ respectively. The $R^{2}(0.9777)$ was relatively high, thus making the Freundlich isotherm a better model compared to the Langmuir (0.4238) (Table 5).

\subsubsection{Temkin isotherm model}

Estimated Temkin isotherm parameters A and B were $6.0670 \mathrm{I} \mathrm{g}^{-1}$ and $1.2408 \mathrm{~J} \mathrm{~mol}^{-1}$, respectively, (Fig. 14), with an $R^{2}$ value of 0.9883 , which is higher than the $R^{2}$ values of 0.4238 and 0.9777 obtained for Freundlich and Langmuir, suggesting that the data better fitted Temkin isotherm than the other two.

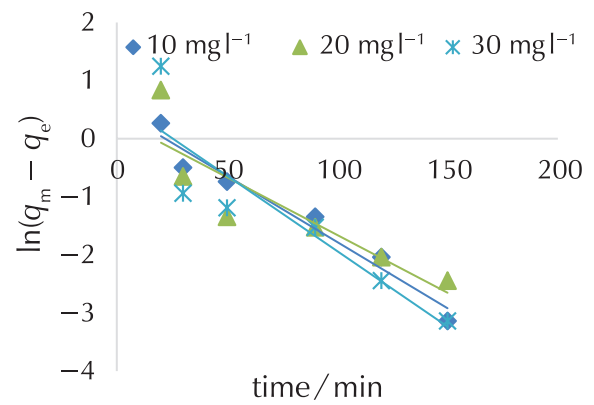

Fig. 16 - Plot of $\ln \left(q_{\mathrm{m}}-q_{\mathrm{e}}\right)$ against time for the effect of concentration

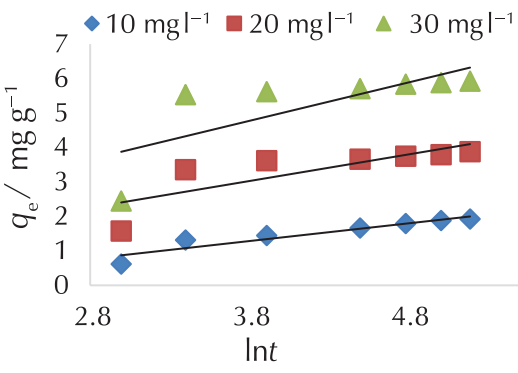

Fig. 18 - Plot of $q_{\mathrm{e}}$ against Int for the effect of concentration

\subsubsection{Dubinin-Radushkevich isotherm for the effect of concentration}

The Dubinin-Radushkevich isotherm model is described by the plot of $\ln q_{\mathrm{e}}$ against $E^{2}$ (Fig. 15) and the estimated parameters, $q_{\mathrm{m}}$ and $\beta$ are $25.1851 \mathrm{mgg}^{-1}$ and $1 \cdot 10^{6} \mathrm{KJ}^{2} \mathrm{~mol}^{2}$, respectively.

The mean free energy of biosorption $\beta$ determines the biosorption mechanism as either a physical or chemical process. The biosorption process is chemically driven if the value of $\beta$ is greater than $8 \mathrm{KJ}^{2} \mathrm{~mol}^{2}$, but involves physical mechanism if less. The value obtained in this study indicated that the adsorption of naphthalene onto AWEPs was driven by a chemical process. The $R^{2}$ value was 0.9949 , which was the highest of all the isotherm models investi-

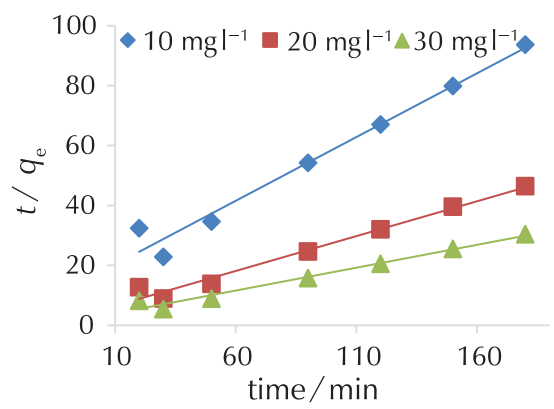

Fig. 17 - Plot of $t / q_{\mathrm{e}}$ against time for the effect of concentration

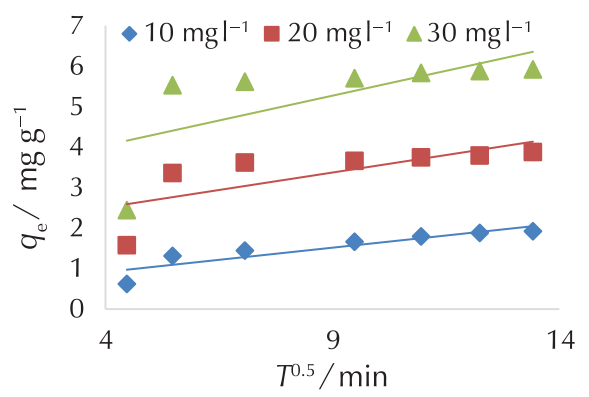

Fig. 19 - Plot of $q_{\mathrm{e}}$ against $T^{0.5}$ for the effect of concentration 
gated, thereby giving the order of suitability as Langmuir < Freundlich < Temkin < Dubinin-Radushkevich isotherm. Therefore, Dubinin-Radushkevich isotherm model best fits the experimental data generated for the adsorption of naphthalene on AWEPs.

\subsection{Investigation of adsorption kinetics}

\subsubsection{Pseudo-first-order kinetics model}

The estimated $k_{1}$ values of $0.023,0.020$, and 0.026 had no visible trend (Fig. 16, Table 7). There is a wide disparity between the calculated equilibrium adsorption capacity $q_{e, \text { calc }}$ and the experimental equilibrium adsorption capacity $\left(q_{\mathrm{e}, \text { exp }}\right)$ values, contrary to a good correlation expected. ${ }^{58}$ This suggests that the adsorption of naphthalene onto AWEPs does not fit the first-order kinetics. The $R^{2}$ for 10 , 20 , and $30 \mathrm{mgl}^{-1}$ are $0.9609,0.7838$, and 0.8034 , respectively and are relatively high. ${ }^{31}$

Table 8 - Kinetic parameters obtained for the kinetics models

\begin{tabular}{|c|c|c|c|c|}
\hline Kinetics model & Parameters & $10 \mathrm{mgl}^{-1}$ & $20 \mathrm{mgl}^{-1}$ & $30 \mathrm{mgl}^{-1}$ \\
\hline \multirow[t]{4}{*}{$\begin{array}{l}\text { Pseudo-first } \\
\text { order }\end{array}$} & $q_{\mathrm{e}, \mathrm{cal}} / \mathrm{mgg}^{-1}$ & 1.648 & 1.389 & 1.933 \\
\hline & $q_{e, e x p} / m g g ~ g^{-1}$ & 1.922 & 3.878 & 5.922 \\
\hline & $K_{1} / \min ^{-1}$ & 0.023 & 0.020 & 0.026 \\
\hline & $R^{2}$ & 0.9609 & 0.7838 & 0.8034 \\
\hline \multirow[t]{4}{*}{$\begin{array}{c}\text { Pseudo-second } \\
\text { order }\end{array}$} & $q_{\mathrm{e}, \mathrm{cal}} / \mathrm{mg} \mathrm{g}^{-1}$ & 2.349 & 4.297 & 6.545 \\
\hline & $q_{e, e x p} / \mathrm{mgg}^{-1}$ & 1.922 & 3.878 & 5.922 \\
\hline & $K_{2} / \mathrm{g} \mathrm{mg}^{-1} \mathrm{~min}^{-1}$ & 0.011 & 0.013 & 0.010 \\
\hline & $R^{2}$ & 0.9750 & 0.9804 & 0.9785 \\
\hline \multirow[t]{3}{*}{ Elovich } & A & 0.140 & 0.872 & 1.816 \\
\hline & B & 1.951 & 1.298 & 0.900 \\
\hline & $R^{2}$ & 0.8905 & 0.6349 & 0.5503 \\
\hline \multirow[t]{3}{*}{$\begin{array}{l}\text { Intraparticle } \\
\text { diffusion }\end{array}$} & $K_{\text {id }}$ & 0.120 & 0.172 & 0.246 \\
\hline & C & 0.434 & 1.821 & 3.060 \\
\hline & $R^{2}$ & 0.8194 & 0.5322 & 0.4504 \\
\hline
\end{tabular}

\subsubsection{Pseudo-second-order kinetics model for the effect of concentration}

The $q_{\mathrm{e} \text {. cal }}$ obtained from the plot of $t / q_{\mathrm{e}} v s t$ (Fig. 17) were $2.349,4.297$, and $6.545 \mathrm{mg} \mathrm{l}^{-1}$, showing a direct relationship with the increase in concentration. The values of $q_{\text {e.cal }}$ were relatively closer to the values of $q_{\text {e,exp }}$. The values of $K_{2}\left(0.011,0.013\right.$, and $\left.0.010 \mathrm{~g} \mathrm{mg}^{-1} \mathrm{~min}^{-1}\right)$ had no particular pattern with increasing concentration. The $R^{2},(0.9750$, 0.9804 , and 0.978 ) were higher than the $R^{2}$, obtained for the first-order model (Table 7).

\subsubsection{Elovich kinetic model}

The plot of $q_{\mathrm{e}}$ against Int for Elovich kinetic model (Fig. 18) gave the values of initial adsorption rate, $\alpha$ as $0.14,0.872$, and 0.814 , while the rate of surface coverage, $\beta$, were $1.951,1.298$, and 1.900 for 10,20 and $30 \mathrm{mgl}^{-1}$, respectively. The $R^{2}(0.8905,0.6349$, and 0.5503$)$ displayed an inverse relation with the initial concentration. The increasing order of suitability of the kinetic models, based on $R^{2}$ obtained, was Elovich $<$ pseudo-first-order $<$ pseudo-second-order kinetic model. Therefore, the adsorption experiment of naphthalene onto AWEPs is best described by the pseudo-second-order kinetic model.

\subsubsection{Intraparticle diffusion model}

The kinetic parameter $(\mathrm{C})$ obtained from the plot of $q_{\mathrm{e}}$ against $t^{\frac{1}{2}}$ (Fig. 19) was $0.434,1.821$, and 3.06 for 10,20 , and $30 \mathrm{mgl}^{-1}$, respectively, implying that values of $C$ were directly proportional to the surface adsorption of naphthalene in the rate-controlling step. The intraparticle diffusion rate constant, $K_{\mathrm{id}}$, values were $0.12,0.172$, and 0.246 , showing that $K_{\text {id }}$ increased with concentration. Intraparticle diffusion becomes the sole rate-limiting step if the plot is linear and passes through the origin..$^{59}$ This study deviated from this condition, thus, intraparticle diffusion is not the sole rate-limiting step. The $R^{2}$ value obtained reduced with increasing concentration.

\subsection{Error analysis for the kinetic models}

It was found that the $\operatorname{SSE}_{\text {(pseudo-first-order) }}$ value for the effect of concentration ranged between 0.017 and 0.89, while the value obtained for the pseudo-second-order ranged between 0.260 and 0.054 . ARE (pseudo-first-order) value for the effect of concentration was greater than $9 \%$, while $\mathrm{ARE}_{\text {(pseudo-second-order) }}$ value for the same factor was less than $4 \%$ (Table 8). Therefore, the pseudo-second order model better predicts the adsorption of naphthalene on AWEPs than the pseudo-first order model.

Table 9 - SSE and ARE values for kinetic models

\begin{tabular}{c|c|c|c}
\hline Kinetic model & Concentration $/ \mathrm{mgl}^{-1}$ & SSE & ARE $/ \%$ \\
\hline pseudo-first order & 10 & 0.0107 & 2.0366 \\
\hline & 15 & 0.8850 & 9.1689 \\
\hline \multirow{2}{*}{ pseudo-second order } & 20 & 0.5698 & 9.6227 \\
\hline & 10 & 0.0260 & 3.1737 \\
\hline & 15 & 0.0250 & 1.5435 \\
\hline
\end{tabular}

\section{Conclusion}

This research successfully demonstrated the suitability of expanded polystyrene waste (WEPs) products as an effective adsorbent. The activant (acetylene) used improved the 
surface characteristics of the AWEPs, and this influenced its adsorptive properties, particularly for the removal of naphthalene from aqueous solution. The adsorption process was chemically driven, as suggested by the fitness of the data generated to Dubinin-Radushkevich isotherm and pseudo-second-order kinetic models. This, therefore, opens more opportunities to explore the WEPs for the adsorption of organic pollutants from aqueous solution and real-life wastewater.

\section{List of abbreviations and symbols}

$$
\begin{array}{ll}
\text { a_k } & - \text { Khan model exponent } \\
b_{-} k & - \text { Khan constant } \\
A^{-} & - \text {Temkin isotherm constant }
\end{array}
$$

ANOVA - analysis of variance

ARE - average relative error at monolayer coverage

AWEPS - acetylated waste expanded polystyrene

b $\quad-$ heat of adsorption constant

$B \quad-$ Temkin isotherm constant

BET - Brannuer-Emmet-Teller method

d - interlayer spacing, $m$

DOE - design of experiment

EPS - expanded polystyrene

FTIR - Fourier transform infrared spectroscopy

H $\quad$ - standard enthalpy, $\mathrm{J} \mathrm{mol}^{-1}$

$h \quad-$ initial adsorption rate as $t \rightarrow 0, \mathrm{mgg}^{-1} \mathrm{~min}^{-1}$

IMR - impregnation ratio

$K_{1} \quad$ - rate constant of pseudo-first order adsorption, $1 / \mathrm{min}$

$K_{2} \quad$ - rate constant of the pseudo-second, $\mathrm{g} \mathrm{mg}^{-1} \mathrm{~min}^{-1}$

$k_{\text {diff }}-$ rate constant for intraparticle diffusion, $\mathrm{m} \mathrm{g}^{-1} \mathrm{~min}^{-1}$

$k_{\mathrm{F}} \quad-$ Freundlich constant

$K_{\mathrm{L}} \quad-$ free energy of adsorption constant

MBN - methylene blue number

MW - microwave

$n-$ Hill coefficient of binding interaction of the adsorbate

OFAT - one factor at a time

PAHs - polycyclic aromatic hydrocarbons

$q_{\mathrm{e}} \quad-$ adsorption capacity at equilibrium, $\mathrm{mgg}^{-1}$

$q_{\mathrm{m}} \quad$ - maximum adsorption capacity, $\mathrm{mg} \mathrm{g}^{-1}$

$q_{\mathrm{s}} \quad$ - theoretical isotherm saturation capacity, $\mathrm{mgg}^{-1}$

$q_{\mathrm{t}} \quad-$ adsorption capacity at time $t, \mathrm{mgg}^{-1}$

$r \quad$ - inverse power of distance from the surface, $\mathrm{m}^{-1}$

$R \quad$ - universal gas constant, $\mathrm{J} \mathrm{mol}^{-1} \mathrm{~K}^{-1}$

RE - removal efficiency

RSM - response surface methodology

SSE - sum of square error

$T$ - absolute temperature, $\mathrm{K}$

V - volume, $\mathrm{dm}^{3}, \mathrm{~cm}^{3}$
WEPS - waste expanded polystyrene

$\Delta G \quad$ - change in Gibbs free energy, $\mathrm{J} \mathrm{mol}^{-1}$

$\Delta S \quad$ - standard entropy change, $\mathrm{JK}^{-1}$

$\beta-$ free energy of adsorption per mole, $\mathrm{KJ}^{2} \mathrm{~mol}^{2}$

$\varepsilon \quad-$ Polanyi potential, $\mathrm{J} \mathrm{mol}^{-1}$

$\gamma_{\mathrm{e}} \quad$ - equilibrium concentration, $\mathrm{mgl}^{-1}$

$\gamma_{\mathrm{o}} \quad-$ adsorbate initial concentration, $\mathrm{mgl}^{-1}$

$\theta-$ degree of surface coverage

\section{References \\ Literatura}

1. X. M. Xiao, F. Tian, Y. J. Yan, Z. S. Wu, Adsorption behaviour of pyrene from onto coal based activated carbons prepared by microwave activation, J. Shihezi Univ. 32 (2014) 485-490.

2. Q. Chen, T. Zheng, B. Bassig, Y. Cheng, B. Leadener, S. Lin, T. Holford, J. Qiu, Y. Zheng, K. Shi, Y. Zhu, J. Niu, Y. Li, H. Guo, $X$. Hu, Y. Jin, Prenatal exposure to polyaromatic hydrocarbons and birth weight in China, Open J. Air Pollut. 3 (2014) 100-110, doi: https://doi.org/10.4236/ojap.2014.34010.

3. S. S. Cai, J. A. Syage, K. A. Hanold, M. P. Balogh, Ultra-performance liquid chromatography atmospheric pressure photoionization tandem mass spectrometry for high-sensitivity and high throughput analysis of U.S. Environmental Protection Agency 16 priority pollutants polynuclear aromatic hydrocarbons, Anal. Chem. 81 (2009) 2123-2128, doi: https://doi.org/10.1021/ac802275e.

4. K. Edvinas, M. Dainius, S. V. Ruta, C. Darius, P. Tedas, K. Violeta, S. Inga, K. Linas, Characterization of particulate and vapor phase polycyclic aromatic hydrocarbons in indoor and outdoor air of primary schools, Atmos. Environ. J. 82 (2014) 298-306, doi: https://doi.org/10.1016/j.atmosenv.2013.10.042.

5. S. M. Yakout, A. A. Daifullah, S. A. El-Reefy, Adsorption of Naphthalene, Phenanthrene, and Pyrene from Aqueous Solution Using Low-Cost Activated Carbon Derived from Agricultural Waste, J. Adsorpt. Sci. Technol. 31 (2013) 334658, doi: https://doi.org/10.1260/0263-6174.31.4.293.

6. R. J. Krupadam, M. S. Khan, S. R. Wate, Removal of Probable Human Carcinogenic Polycyclic Aromatic Hydrocarbons from Contaminated Water Using Molecularly Imprinted Polymer, Water Res. 44 (2010) 681-688, doi: https://doi. org/10.1016/j.watres.2009.09.044.

7. R. Quiroz, J. O. Grimalt, P. Fernandez, Toxicity assessment of polycyclic aromatic hydrocarbons in sediments from European high mountain lakes, Ecotoxicol. Environ. Saf. 73 (2010) 559-1564, doi: https://doi.org/10.1016/j. ecoenv.2009.12.030.

8. A. O. Alade, O. S. Amuda, T. J. Afolabi, A. A. Okoya, Adsorption of Naphthalene onto Activated Carbons Derived from Milk Bush Kernel Shell and Flamboyant Pod, J. Environ. Chem. Ecotoxicol. 4 (2012) 124-132, doi: https://doi. org/10.5897/JECE11.041.

9. A. A. Olajiire, A. O. Alade, A. A. Adejare, O. M. Olabemiwo, Distribution of Polycyclic aromatic hydrocarbons in surface soils and water from the vicinity of Agbabu bitumen field of southwestern Nigeria, J. Environ. Sci. Health A 42 (2007) 1043104, doi: https://doi.org/10.1080/10934520701418474.

10. F. Murilo, T. Luna, C. B. Araujo, B. V. Carolina, J. Ivanildo, Jr. Silva, C. S. Diana, L. Celio, Jr. Cavalcante, Adsorption of 
Naphthalene and Pyrene from Isooctane Solutions on Commercial Activated Carbons, J. Environ. Sci. 17 (2011) 937947, doi: https://doi.org/10.1007/s10450-011-9372-0.

11. L. Monser, N. Adhoum, Modified Activated Carbon for the Removal of Copper, Zinc, Chromium, and Cyanide from Wastewater, J. Sep. Purif. Technol. 26 (2002) 137-146, doi: https://doi.org/10.1016/S1383-5866(01)00155-1.

12. A. Daifullah, B. Girgis, H. Gad, Utilization of Agro-Residues (Rice-Husk) in Small Wastewater Treatment Plans, J. Waste Manag. 11 (2003) 1723-1731, doi: https://doi.org/10.1016/ S0167-577X(02)01058-3.

13. L. Seifi, A. Torabian, H. Kazemian, G. N. Bidhendi, A. A. Azimi, S. Nazmara, M. Alimohammadi, Adsorption of BTEX on Surfactant Modified Granulated Natural Zeolite Nanoparticles: Parameters Optimizing by Applying Taguchi Experimental Design Method, J. Water Air Soil Pollut. 39 (2011) 939-948, doi: https://doi.org/10.1002/clen.201000390.

14. F. Yu, J. Ma, Y. Wu, Adsorption of Toluene, Ethylbenzene, and Xylene Isomers on Multi-Walled Carbon Nanotubes Oxidized by Different Concentration of $\mathrm{NaOCl}$, J. Environ. Technol. 3 (2011) 320-329, doi: https://doi.org/10.1007\%2 Fs11783-011-0340-4

15. Y. Zhao, H. Zhang, P. Wang, F. Xue, Z. Ye, Y. Zhang, Y. Tang, Tailoring the Morphology of MTW Zeolite Mesocrystals: Intertwined Classical/Non-Classical Crystallization, J. Chem. Mater. 19 (2017) 1058-1062, doi: https://doi.org/10.1021/ acs.chemmater.6b03813.

16. H. Nourmoradi, M. Nikaeen, H. H. Khiadani, Removal of Benzene, Toluene, Ethylene, Chem. Eng. J. 191 (2012) 341348, doi: https://doi.org/10.1016/j.cej.2012.03.029.

17. L. Touyz, Naphthalene Mothballs: A Silent Killer, NOVA publisher, NY11788, USA, 2014.

18. C. H. Micheal, Fact sheet on Naphthalene, Cancer Association of South Africa, 2015.

19. E. Ayranci, O. Duman, Structural Effects on the Interactions of Benzene and Naphthalene Sulfonates with Activated Carbon Cloth during Adsorption from Aqueous Solutions, Chem. Eng. J. 156 (2010) 70-76, doi: https://doi.org/10.1016/j. cej.2009.09.038.

20. S. E. Agarry, M. O. Aremu, Batch Equilibrium and Kinetic Studies of Simultaneous Adsorption and Biodegradation of Naphthalene by Orange Peels Immobilized Pseudomonas Aeruginosa NCIB 950, J. Bioremed. Biodegrad. 3 (2012) 138, doi: https://doi.org/10.9734/BBJ/2012/902.

21. X. Ge, F. Tian, Z. Wu, Y. Yan, G. Cravotto, Z. Wu, Adsorption of Naphthalene from Aqueous Solution on Coal-Based Activated Carbon Modified by Microwave Induction: Microwave Power Effects, Chemical Engineering, and Processing, J. Process Intens. 91 (2015) 57-77, doi: https://doi.org/10.1016/j. cep.2015.03.019.

22. E. I. Osagie, C. N. Owabor, Adsorption of Naphthalene on Clay and Sandy Soil from Aqueous Solution, Adv. Chem. Eng. Sci. 5 (2015) 345-351, doi: https://doi.org/10.4236/ aces.2015.53036.

23. G. Karthikeyan, S. Meenakshi, B. V. Apparao, Water Engineering and Development Centre 20, 1994.

24. N. Chaukura, W. Gwenzi, T. Bunhu, D. T. Ruziwa, I. Pumure. Potential Uses and Value-Added Products Derived from Waste Polystyrene in Developing Countries: A review, J. Res. Conserv. Recyc. 107 (2015) 157-165, doi: https://doi. org/10.1016/j.resconrec.2015.10.031.

25. A. Kan, R. Demirboga, A New Technique of Processing for Waste-Expanded Polystyrene Foams as Aggregates, J. Mater. Process. Technol. 209 (2009) 2994-3000, doi: https://doi. org/10.1016/j.jmatprotec.2008.07.017.

26. W. Gwenzi, D. Ruziwa, N. Chaukura, I. Pumure, Removal of $\mathrm{Zn}^{2+}$ and $\mathrm{Pb}^{2+}$ Ions from Aqueous Solution using Sulphonated Waste Polystyrene, J. Environ. Chem. Eng. 3 (2015) 25282537, doi: https://doi.org/10.1016/j.jece.2015.08.006.

27. J. Huang, X. Y. Yin, J. Y. Yang, M. L. Guo, Solid Protonic Acids and Luminescent Carbon Dots Derived from Waste Expanded Polystyrene, J. Mater. Lett. 117 (2013) 112-115, doi: https://doi.org/10.1016/j.matlet.2013.11.104.

28. A. N. Siyal, S. Q. Memon, S. Parveen, A. Soomro, M. I. Khaskheli, M. Y. Khuhawar, Chemical Recycling of Expanded Polystyrene Waste: Synthesis of Novel Functional Polystyrene-Hydrazone Surface for Phenol Removal, J. Chem. 2 (2013) 1020-1035, doi: https://doi.org/10.1155/2013/842435.

29. F. D. Alsewailem, S. A. All, Recycled Polymer/Clay Composites for Heavy-Metals Adsorption, J. Mater. Technol. 47 (2013) 525-529.

30. D. Ruziwa, N. Chaukura, W. Gwenzi, N. Pumure, Removal of $\mathrm{Zn}^{2+}$ and $\mathrm{Pb}^{2+}$ ions from aqueous solution using sulphonated waste polystyrene, J. Environ. Eng. 11 (2015) 1135-1176, doi: https://doi.org/10.1016/j.jece.2015.08.006.

31. O. Alabi, A. O. Alade, T. J. Afolabi, Process optimization of adsorption of $\mathrm{Cr}(\mathrm{VI})$ on adsorbent prepared from Bauhinia rufescence pod by Box-Behnken Design, J. Sep. Sci. Technol. 55 (2020) 47-60, doi: https://doi.org/10.1080/01496395.2 019.1577436 .

32. B. Jenkins, L. Baxter, T. Miles, T. Miles, Combustion Properties of Biomass, J. Fuel Process. Technol. 54 (1998) 17-46, doi: https://doi.org/10.1016/S0378-3820(97)00059-3.

33. O. A. Ekpete, M. Horsfall, Kinetic Sorption Study of Phenol onto Activated Carbon Derived from Fluted Pumpkin Stem Waste (Telfairia Occidentalis Hook. F), J. Eng. Appl. Sci. 6 (2011) 43-49.

34. E. Fuente, J. A. Menendez, M. A. Dyes, D. Sau'rez, M. A. Montes-Moran, Infrared Spectroscopy of Carbon Materials: A Quantum Chemistry Study of Model Compounds, J. Phys. Chem. 1 (2003) 15-24, doi: https://doi.org/10.1021/ jp027482g.

35. Z. Lin, C. Guan, L. Huang, W. Wang, Q. Ling, C. Zhao, Catalysis Studies of Microreticular Polystyrene Cation-exchange Resin with Terminal Perfluoroalkanesulfonic acids, J. Chin. Chem. Soc. 60 (2012) 261-266, doi: https://doi. org/10.1002/jccs.201200431.

36. D. Krishna, R. Padma Sree, Artificial Neural Network and Response Surface Methodology Approach for Modeling and Optimization of Chromium (VI) Adsorption from Waste Water using Ragi Husk Powder, Ind. Chem. Eng. 55 (3) (2013), doi: https://doi.org/10.1080/00194506.2013.829257

37. I. O. Okeowo, E. O. Balogun, A. J. Ademola, A. O. Alade, T. J. Afolabi, E. O. Dada, A. G. Farombi, Adsorption of Phenol from Wastewater Using Microwave-Assisted Ag-Au Nanoparticle-Modified Mango Seed Shell-Activated Carbon, Int. J. Environ. Res. 14 (2020) 215-233, doi: https://doi. org/10.1007/s41742-020-00244-7.

38. S. Saygideger, O. Gulnaz, E. S. Istifli, N. Yucel, Adsorption of $\mathrm{Cd}(\mathrm{II}), \mathrm{Cu}(\mathrm{II})$ and $\mathrm{Ni}(\mathrm{II})$ ions by Lemna minor L.: effect of physicochemical environment, J. Hazard. Mater. 126 (2005) 96104. doi: https://doi.org/10.1016/j.jhazmat.2005.06.012.

39. M. E. Argun, S. Dursun, A New Approach to Modification of Natural Adsorbent for Heavy Metal Adsorption, J. Biores. Technol. 99 (2008) 2516-2527, doi: https://doi. org/10.1016/j.biortech.2007.04.037.

40. O. S. Bello, M. A. Ahmad, Response Surface Modeling and Optimization of Remazol Brilliant Blue Reactive Dye Re- 
moval Using Periwinkle Shell-Based Activated Carbon, J. Sep. Sci. Technol. 46 (2011) 2367-2379, doi: https://doi.or g/10.1080/01496395.2011.595756.

41. N. A. Elnasri, M. A. Elsheik, M. A. Eltayeb, Physico-Chemical Characterization and Freundlich Isotherm of Adsorption of Fe(II) from Aqueous Solution by Using Activated Carbon Prepared from Doum Fruit Waste, Arch. Appl. Sci. Res. 5 (2013) 149-158.

42. A. O. Dada, J. O. Ojediran, A. P. Olalekan, Sorption of $\mathrm{Pb}^{2+}$ from Aqueous Solution unto Modified Rice Husk : Isotherms Studies, J. Adv. Phys. Chem. 16 (2013) 225-286, doi: https:// doi.org/10.1155/2013/842425.

43. A. Adeleh, M. K. Ali, S. Farad, A Kinetic and Thermodynamic Study of Methylene Blue Removal from Aqueous Solution by Modified Montmorillonite, J. Appl. Res. Water Wastewater 4 (2015) 150-155.

44. M. Auta, B. H. Hameed, Acid modified local clay beads as an effective low-cost adsorbent for dynamic adsorption of methylene blue, J. Ind. Eng. Chem. 19 (2013) 1153-1161, doi: https://doi.org/10.1016/j.jiec.2012.12.012.

45. S. Chowdhury, P. D. Saha, Artificial neural network (ANN) modeling of adsorption of methylene blue by $\mathrm{NaOH}$-modified rice husk in a fixed-bed column system, Environ. Sci. Pollut. Res. 20 (2013) 1050-1058, doi: https://doi. org/10.1007/s11356-012-0912-2.

46. Sh. Shahmohammadi-Kalalagh, H. Babazadeh, Isotherms for the Sorption of Zinc and Copper onto Kaolinite Comparison for Various Error Functions, Int. J. Environ. Sci. Technol. 11 (2014) 111-118, doi: https://doi.org/10.1007\%2Fs13762013-0260-х.

47. M. Zbair, M. Bottlinger, R. Brahmi, A. Ainassaari, M. Pirilä, A. Drif, R. L. Keiski, S. Ojala, M. Bensite, Toward new benchmark adsorbents: preparation and characterization of activated carbon from argan nutshell for bisphenol A removal, Environ. Sci. Pollut. Res. 25 (2018) 1869-1882, doi: https:// doi.org/10.1007/s11356-017-0634-6.

48. Z. Fu, J. Jia, J. Li, C. Liu, Transforming Waste Expanded Polystyrene Foam into Hyper-Crosslinked Polymers for Carbon dioxide Capture and Separation, J. Chemi. Eng. 323 (2017) 557-564, doi: https://doi.org/10.1016/j.cej.2017.04.090.

49. C. O. Ania, B. Carbal, J. B. Parra, J. J. Pis, Importance of the Hydrophobic Character of Activated Carbon on the Removal of Naphthalene from the Aqueous Phase, J. Adsorpt. Sci. Technol. 25 (2007), doi: https://doi. org/10.1260/026361707782398164.

50. J. Yang, M. Yu, W. Chen, Adsorption of hexavalent chromium from aqueous solution by activated carbon prepared from longan seed: kinetics, equilibrium, and thermodynamics, J. Ind. Eng. Chem. 21 (2015) 414-422, doi: https://doi. org/10.1016/j.jiec.2014.02.054.

51. M. Rai, G. Shahi, V. Meena, R. Meena, S. Chakraborty, B. Rai, R. Singh, Removal of hexavalent chromium Cr (VI) using activated carbon prepared from mango kernel activated with $\mathrm{H}_{3} \mathrm{PO}_{4}$, J. Res. Effic. Technol. 2 (2016) 63-70, doi: https:// doi.org/10.1016/j.reffit.2016.11.011.

52. S. Yildiz, Kinetic, and Isotherm Analysis of $\mathrm{Cu}(\mathrm{li})$. Adsorption onto Almond Shell (Prunus dulcis), J. Ecol. Chem. Eng. 24 (2017) 87-106, doi: https://doi.org/10.1515/eces-20170007.

53. A. Inyinbor, F. Adekola, G. Olatunji, Kinetics, and isothermal modeling of liquid-phase adsorption of Rhodamine B onto urea modified Raphia hookerie fruit epicarp, J. Water Res. Ind. 15 (2016) 14-27, doi: https://doi.org/10.1007/s13201016-0471-7.

54. B. V. Carla, L. B. Allen, P. M. Cicero, C. A. Ari, S. D. Francisco, C. G. V. Luiz, B. A. F. Pierre, F. N. Ronaldo, Adsorption of Polycyclic Aromatic Hydrocarbon from Aqueous Solutions by Modified Periodic Mesoporous Organosilica, J. Colloid Interface Sci. 357 (2011) 466-473, doi: https://doi. org/10.1016/j.jcis.2011.02.013.

55. H. Hammud, Biosorption Studies of Methylene Blue by Mediterranean Algae Carolina and Its Chemically Modified Forms. Linear and Nonlinear Models Prediction Based on Statistical Error Calculations, Int. J. Chem. 3 (2011) 147-163, DOI: https://doi.org/10.5539/ijc.v3n4p147.

56. C. Chang, C. Chang, K. Chen, W. Tsai, J. Shie, Y. Chen, Adsorption of Naphthalene on Zeolite from Aqueous Solution, J. Colloid Interface Sci. 277 (2004) 29-34, doi: https://doi. org/10.1016/j.jcis.2004.04.022.

57. H. Gupta, B. Gupta, Adsorption of Polycyclic Aromatic Hydrocarbon on Banana Peel Activated Carbon, J. Desal. Water Treat. 57 (2015) 9498-9509, doi: https://doi.org/10.1080/1 9443994.2015.1029007.

58. M. Matouq, N. Jildeh, M. Qtaishat, M. Hindiyeh, M. Al Syouf, The Adsorption Kinetics and Modelling for Heavy Metals Removal from Wastewater by Moringa Pods, J. Environ. Chem. Eng. 3 (2015) 775-784, doi: https://doi.org/10.1016/j. jece.2015.03.027.

59. B. Das, N. K. Mondai, R. Bhaumik, P. Roy, Insight into Adsorption Equilibrium, Kinetics and Thermodynamics of Lead onto Alluvial Soil, J. Environ. Sci. Technol. 11 (2014) 11011114, doi: https://doi.org/10.1007\%2Fs13762-013-0279-z. 


\section{SAŽETAK \\ Recikliranje ekspandiranog polistirena kao učinkovitog adsorbensa naftalena iz vodene otopine}

Oluwayemisi Christiana Taiwo, a,b Tinuade Jolaade Afolabi,a,b

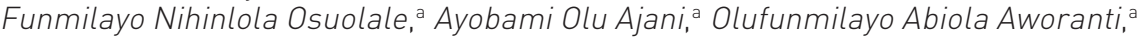
Olabanji Raphael Ogunleye, ${ }^{a, b}$ and Abass Olanrewaju Alade ${ }^{a, b, c^{*}}$

Šaržni faktori procesa adsorpcije [vrijeme kontakta (20 - $150 \mathrm{~min})$, doziranje adsorbenta $(0,5-1,5 \mathrm{~g})$, koncentracija adsorbata $\left(5-30 \mathrm{mg} \mathrm{l}^{-1}\right)$ i brzina miješanja (100-250 $\left.\mathrm{min}^{-1}\right)$ ] optimizirani su na temelju D-optimalnog dizajna primjenom metodologije odzivne površine (RSM) programa Design-Expert (7.6.8) za uklanjanje naftalena iz vodene otopine pomoću adsorbenta razvijenog iz acetiliranog otpadnog ekspandiranog polistirena (AWEP). Ostvareni maksimalni adsorpcijski kapacitet $\left(5,6608 \mathrm{mg} \mathrm{g}^{-1}\right)$ dobro je prilagođen izotermi Dubinin-Radushkevich $\left(R^{2}=0,9949\right)$. SSE $(<0,05)$ i ARE $(<4,0 \%)$ označili su pseudo-drugi red kao najprikladniji model. Ovo istraživanje pokazalo je učinkovitost WEP-a za uklanjanje naftalena iz vodene otopine.

Ključne riječi

Adsorpcija, D-optimalnost, naftalen, otpadni ekspandirani polistiren

a Department of Chemical Engineering, Ladoke Akintola University of Technology,

Izvorni znanstveni rad Ogbomoso, Nigerija Prispjelo 25. prosinca 2020

b Bioenvironmental, Water and Engineering Prihvaćeno 26. lipnja 2021. Research Group, (BWERG), Ladoke Akintola University of Technology Ogbomoso, Nigerija

c Science and Engineering Research Group,

(SEARG), Ladoke Akintola University of Technology Ogbomoso, Nigerija 